\title{
Competition between Phosphorus Lone Pairs and Ring $\pi$-Systems in Binding to Transition Metals: Binuclear Diphosphacyclobutadiene Cobalt Carbonyl Derivatives
}

\author{
Xiaohong Chen, ${ }^{a}$ Yifan Wang, ${ }^{a}$ Rong Jin, ${ }^{a}$ Quan Du, ${ }^{a}$ Hao Feng, ${ }^{a *}$ Yaoming Xie, ${ }^{b}$ \\ and R. Bruce King ${ }^{* b}$ \\ ${ }^{a}$ School of Sciences and Research Center for Advanced Computation, Xihua \\ University, Chengdu, China 610039 \\ ${ }^{b}$ Department of Chemistry and Center for Computational Quantum Chemistry \\ University of Georgia, Athens, Georgia 30602, USA \\ E-mail: Fenghao@mail.xhu.edu.cn; rbking@chem.uga.edu
}

\begin{abstract}
Metal complexes of the 2,4-di-t-butyl-1,3-diphosphacyclobutadiene ligand have been synthesized by head-to-tail dimerization of $\mathrm{t}-\mathrm{BuC} \equiv \mathrm{P}$ : on transition metal sites. In this connection the geometries and energetics of the complete series of binuclear cobalt carbonyl complexes $\left(\mathrm{Me}_{2} \mathrm{C}_{2} \mathrm{P}_{2}\right)_{2} \mathrm{Co}_{2}(\mathrm{CO})_{n}(n=5,4,3,2,1)$ of the simpler 2,4-dimethyl1,3-diphosphacyclobutadiene ligand have been investigated by density functional theory. The lowest energy structures of these complexes have bridging $\eta^{4}, \eta^{1}-\mathrm{Me}_{2} \mathrm{C}_{2} \mathrm{P}_{2}$ ligands donating six electrons to the central $\mathrm{Co}_{2}$ unit through a tetrahapto ring-metal linkage to one cobalt atom and a phosphorus lone pair to the other cobalt atom. For the tetracarbonyl $\left(\mathrm{Me}_{2} \mathrm{C}_{2} \mathrm{P}_{2}\right)_{2} \mathrm{Co}_{2}(\mathrm{CO})_{4}$ doubly CO-bridged structures with terminal $\eta^{4}-\mathrm{Me}_{2} \mathrm{C}_{2} \mathrm{P}_{2}$ ligands similar to known $\left(\eta^{5}-\mathrm{C}_{5} \mathrm{H}_{5}\right)_{2} \mathrm{Fe}_{2}(\mu-\mathrm{CO})_{2}(\mathrm{CO})_{2}$ and $\left(\eta^{4}-\mathrm{Me}_{4} \mathrm{C}_{4}\right)_{2} \mathrm{Co}_{2}(\mu-\mathrm{CO})_{2}(\mathrm{CO})_{2}$ structures lie only $\sim 5 \mathrm{kcal} / \mathrm{mol}$ in energy above the $\eta^{4}, \eta^{1}-\mathrm{Me}_{2} \mathrm{C}_{2} \mathrm{P}_{2}$ bridged structures. For the unsaturated $\left(\mathrm{Me}_{2} \mathrm{C}_{2} \mathrm{P}_{2}\right)_{2} \mathrm{Co}_{2}(\mathrm{CO})_{3}$ and $\left(\mathrm{Me}_{2} \mathrm{C}_{2} \mathrm{P}_{2}\right)_{2} \mathrm{Co}_{2}(\mathrm{CO})_{2}$ systems, structures with one or two bridging $\eta^{4}, \eta^{1}-\mathrm{Me}_{2} \mathrm{C}_{2} \mathrm{P}_{2}$ ligands, respectively, are preferred energetically over isomeric structures with formal $\mathrm{Co}=\mathrm{Co}$ double bonds and $\mathrm{Co} \equiv \mathrm{Co}$ triple bonds, respectively. The lowest energy structure for the monocarbonyl $\left(\mathrm{Me}_{2} \mathrm{C}_{2} \mathrm{P}_{2}\right)_{2} \mathrm{Co}_{2}(\mathrm{CO})$ is a triplet structure in which a $\left(\mathrm{Me}_{2} \mathrm{C}_{2} \mathrm{P}_{2}\right)_{2} \mathrm{Co}$ sandwich unit functions as a tridentate ligand to a $\mathrm{CoCO}$ unit through a phosphorus atom on each ring as well as the central cobalt atom.
\end{abstract}




\section{Introduction}

The recognition of phosphorus as a carbon copy [1] suggests the replacement of $\mathrm{CH}$ groups in planar carbocyclic ligands to give phosphorus heterocyclic ligands having similar $\pi$-systems as their carbocyclic analogues for binding to a transition metal moiety. However, phosphorus atoms replacing $\mathrm{CH}$ groups in such ring systems have lone pairs that can coordinate with transition metals. Recently we have been using density functional theory to explore the competition between ring $\pi$-systems and phosphorus lone pairs in binding to transition metals in binuclear metal carbonyl derivatives.

The phospholyl ligand $\mathrm{C}_{4} \mathrm{H}_{4} \mathrm{P}$ is closely related to the cyclopentadienyl ligand by replacement of one $\mathrm{CH}$ group with a phosphorus atom. Thus the $\eta^{5}$-phospholyl manganese carbonyl $\left(\eta^{5}-\mathrm{C}_{4} \mathrm{H}_{4} \mathrm{P}\right) \mathrm{Mn}(\mathrm{CO})_{3}$ as well as its more readily available 3,4-dimethyl derivative $\left(\eta^{5}-3,4-\mathrm{C}_{4} \mathrm{H}_{2} \mathrm{Me}_{2} \mathrm{P}\right) \mathrm{Mn}(\mathrm{CO})_{3}$, analogous to the very stable $\left(\eta^{5}-\mathrm{C}_{5} \mathrm{H}_{5}\right) \mathrm{Mn}(\mathrm{CO})_{3}$, were synthesized by Mathey and coworkers [2, 3] in 1976 using thermal reactions of the corresponding P-phenylphosphole with $\mathrm{Mn}_{2}(\mathrm{CO})_{10}$. Theoretical studies on the corresponding binuclear phospholyl $\left(\mathrm{C}_{4} \mathrm{H}_{4} \mathrm{P}\right)_{2} \mathrm{Mn}_{2}(\mathrm{CO})_{n}$ pentacarbonyl and tetracarbonyl systems $(n=5,4)$ show that the lowest energy structures differ from the corresponding $\left(\mathrm{C}_{5} \mathrm{H}_{5}\right)_{2} \mathrm{Mn}_{2}(\mathrm{CO})_{n}$ structures by involving the phosphorus lone pairs in preference to manganese-manganese bonding [4]. Only for the tricarbonyls $\left(\mathrm{C}_{4} \mathrm{H}_{4} \mathrm{P}\right)_{2} \mathrm{Mn}_{2}(\mathrm{CO})_{3}$ and $\left(\mathrm{C}_{5} \mathrm{H}_{5}\right)_{2} \mathrm{Mn}_{2}(\mathrm{CO})_{3}$ with formal $\mathrm{Mn} \equiv \mathrm{Mn}$ triple bonds do the lowest energy phospholyl and cyclopentadienyl derivatives have analogous structures. However, for the similar phospholyl derivatives of the later first row transition metals iron and cobalt the phosphorus lone pair does not play a role in the lowest energy structures so $\left(\mathrm{C}_{4} \mathrm{H}_{4} \mathrm{P}\right)_{2} \mathrm{M}_{2}(\mathrm{CO})_{n}$ and $\left(\mathrm{C}_{5} \mathrm{H}_{5}\right)_{2} \mathrm{M}_{2}(\mathrm{CO})_{n}(\mathrm{M}=\mathrm{Fe}$ [5], $\mathrm{Co}[6])$ are predicted to exhibit analogous structures.

Diphosphorus analogues of the cyclobutadiene ligand are also known in which two of the $\mathrm{CH}$ groups of cyclobutadiene have been replaced by phosphorus atoms. Thus headto-tail dimerization of phosphaalkynes $\mathrm{RC} \equiv \mathrm{P}$ : $(\mathrm{R}=$ bulky alkyl group such as tert-butyl) on transition metal sites leads to metal complexes of the 2,4-di-t-butyl-1,3-diphosphacyclobutadiene ligand (Figure 1) [7]. For example, reaction of $\mathrm{tBuC} \equiv \mathrm{P}$ : with $\left(\eta^{2,2}-\mathrm{C}_{8} \mathrm{H}_{12}\right)_{2} \mathrm{Ni}$ gives the very stable nickel sandwich compound $\left(\eta^{4}-\mathrm{tBu}_{2} \mathrm{C}_{2} \mathrm{P}_{2}\right)_{2} \mathrm{Ni}$ with the favored 18-electron nickel configuration [8]. Similar anionic cobalt and iron sandwich compounds $\left[\left(\eta^{4}-\mathrm{HBu}_{2} \mathrm{C}_{2} \mathrm{P}_{2}\right)_{2} \mathrm{M}\right]^{-}(\mathrm{M}=\mathrm{Co}$ [9], Fe [10]) have been synthesized by displacement of coordinated anthracene from the anions $\left[\left(\eta^{4}-\mathrm{C}_{14} \mathrm{H}_{10}\right)_{2} \mathrm{M}\right]^{-}$with $\mathrm{tBuC} \equiv \mathrm{P}$.. These can be oxidized to the corresponding neutral species $\left(\eta^{4}-\mathrm{tBu}_{2} \mathrm{C}_{2} \mathrm{P}_{2}\right)_{2} \mathrm{M}$. The very stable metal carbonyl derivative $\left(\eta^{4}-\mathrm{tBu}_{2} \mathrm{C}_{2} \mathrm{P}_{2}\right) \mathrm{Fe}(\mathrm{CO})_{3}$ is obtained by the direct thermal reaction of $\mathrm{tBuC} \equiv \mathrm{P}$ : with $\mathrm{Fe}(\mathrm{CO})_{5} \quad[11$ ]. In addition, the mixed sandwich compound 
$\left(\eta^{5}-\mathrm{tBu}_{3} \mathrm{C}_{5} \mathrm{H}_{2}\right) \mathrm{Co}\left(\eta^{4}-\mathrm{tBu}_{2} \mathrm{C}_{2} \mathrm{P}_{2}\right)$ has been synthesized by reaction of $\left(\eta^{5}-\mathrm{tBu}_{3} \mathrm{C}_{5} \mathrm{H}_{2}\right) \mathrm{Co}$ $\left(\eta^{6,6}-\mathrm{MeC}_{6} \mathrm{H}_{5}\right) \mathrm{Co}\left(\eta^{5}-\mathrm{C}_{5} \mathrm{H}_{2} \mathrm{HBu}_{3}\right)$ with $\mathrm{tBuC} \equiv \mathrm{P}$ : [12]. In addition to these transition metal 1,3-diphosphacyclobutadiene complexes obtained by reactions of $\mathrm{RC} \equiv \mathrm{P}$ : with various transition metal derivatives, substituted 1,3-diphosphacyclobutadiene dianions have been synthesized as their dilithium salts $[13,14]$. They are also reagents that can be used for the synthesis of 1,3-diphosphacyclobutadiene metal complexes.

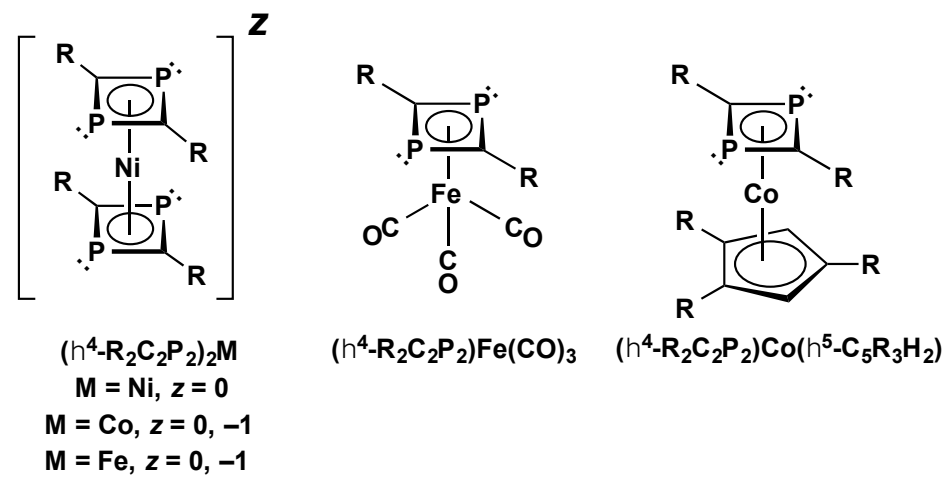

Figure 1. Examples of 1,3-diphosphacyclobutadiene metal complexes containing tetrahapto $\eta^{4}-\mathrm{R}_{2} \mathrm{C}_{2} \mathrm{P}_{2}$ ligands that have been synthesized and characterized structurally by $\mathrm{X}$-ray diffraction. In these structures $\mathrm{R}$ is typically tert-butyl.

The ligand-metal bonding in all of these $\eta^{4}-\mathrm{tBu}_{2} \mathrm{C}_{2} \mathrm{P}_{2}$ metal complexes uses only the $\pi$-orbitals of the essentially planar $\eta^{4}-\mathrm{BBu}_{2} \mathrm{C}_{2} \mathrm{P}_{2}$ ring without involvement of the phosphorus lone pair. However, these metal complexes can function as ligands to other transition metal systems by using the phosphorus lone pairs in their coordinated 1,3-diphosphacyclobutadiene rings (Figure 2). For example, the basicity of the phosphorus atoms in the iron carbonyl complex $\left(\mathrm{tBu}_{2} \mathrm{C}_{2} \mathrm{P}_{2}\right) \mathrm{Fe}(\mathrm{CO})_{3}$ is indicated by the synthesis of the chromium pentacarbonyl complex $\left[\mathrm{tBu}_{2} \mathrm{C}_{2} \mathrm{P}_{2} \rightarrow \mathrm{Cr}(\mathrm{CO})_{5}\right] \mathrm{Fe}(\mathrm{CO})_{3}$ [15]. Similarly, a ring phosphorus atom in $\left(\eta^{5}-\mathrm{BBu}_{3} \mathrm{C}_{5} \mathrm{H}_{2}\right) \mathrm{Co}\left(\eta^{4}-\mathrm{tBu}_{2} \mathrm{C}_{2} \mathrm{P}_{2}\right)(=\mathrm{L})$ can function as a monodentate ligand in metal carbonyl chemistry leading, for example, to tungsten carbonyl complexes of the type trans $-\mathrm{L}_{2} \mathrm{~W}(\mathrm{CO})_{4}[12]$. In addition, reaction of the thallium(I) salt of $\left[\left(\eta^{4}-\mathrm{tBu}_{2} \mathrm{C}_{2} \mathrm{P}_{2}\right)_{2} \mathrm{Co}\right]$ with $\left(\eta^{4}-\mathrm{Me}_{4} \mathrm{C}_{4}\right) \mathrm{Co}(\mathrm{CO})_{2}$ I gives the complex $\left(\eta^{4}-\mathrm{Me}_{4} \mathrm{C}_{4}\right) \mathrm{Co}(\mathrm{CO})_{2} \mathrm{Co}\left(\mathrm{P}_{2} \mathrm{C}_{2}+\mathrm{Bu}_{2}\right)_{2}$ in which a phosphorus atom of one of the coordinated 1,3-diphosphacyclobutadiene rings is bonded to the $\left(\eta^{4}-\mathrm{Me}_{4} \mathrm{C}_{4}\right) \mathrm{Co}(\mathrm{CO})_{2}$ unit [16]. In such compounds, an $\left(\eta^{4}, \eta^{1}-\mathrm{BBu}_{2} \mathrm{C}_{2} \mathrm{P}_{2}\right)$ ring bridging two metal atoms functions as a six-electron donor to the bimetallic system.

In order to evaluate the effects of basicity of the ring phosphorus atoms in 1,3-diphosphacyclobutadiene metal complexes, we have studied the structures and thermochemistry of the binuclear metal carbonyl complexes $\left(\mathrm{Me}_{2} \mathrm{C}_{2} \mathrm{P}_{2}\right)_{2} \mathrm{M}_{2}(\mathrm{CO})_{n}(\mathrm{M}=\mathrm{Fe}$ [17], Mn [18]; $n=5,4,3,2$ ) complexes using density functional theory for comparison with the 
corresponding binuclear cyclobutadiene metal carbonyls $\left(\mathrm{C}_{4} \mathrm{H}_{4}\right)_{2} \mathrm{M}_{2}(\mathrm{CO})_{n}(\mathrm{M}=\mathrm{Fe}$ [19], Mn [20]). Methyl rather than tert-butyl ring substituents were used in order to facilitate the calculations. For the two carbonyl-richest systems, namely $\left(\mathrm{Me}_{2} \mathrm{C}_{2} \mathrm{P}_{2}\right)_{2} \mathrm{M}_{2}(\mathrm{CO})_{n}(\mathrm{M}=$ Fe, $n=5,4 ; \mathrm{M}=\mathrm{Mn}, n=6,5)$ the lowest energy structures were found to have two mononuclear $\left(\mathrm{Me}_{2} \mathrm{C}_{2} \mathrm{P}_{2}\right) \mathrm{M}(\mathrm{CO})_{m}$ units joined by $\mathrm{P} \rightarrow \mathrm{M}$ dative bonds using the lone pairs of the phosphorus atoms in bridging diphosphacyclobutadiene rings. However, low-energy structures were found for $\left(\mathrm{Me}_{2} \mathrm{C}_{2} \mathrm{P}_{2}\right)_{2} \mathrm{Fe}_{2}(\mathrm{CO})_{3}$ and $\left(\mathrm{Me}_{2} \mathrm{C}_{2} \mathrm{P}_{2}\right)_{2} \mathrm{Mn}_{2}(\mathrm{CO})_{4}$ having terminal $\eta^{4}-\mathrm{Me}_{2} \mathrm{C}_{2} \mathrm{P}_{2}$ rings with short $\mathrm{M} \equiv \mathrm{M}$ distances indicating the formal triple bonds required to give each metal atom the favored 18-electron configuration.
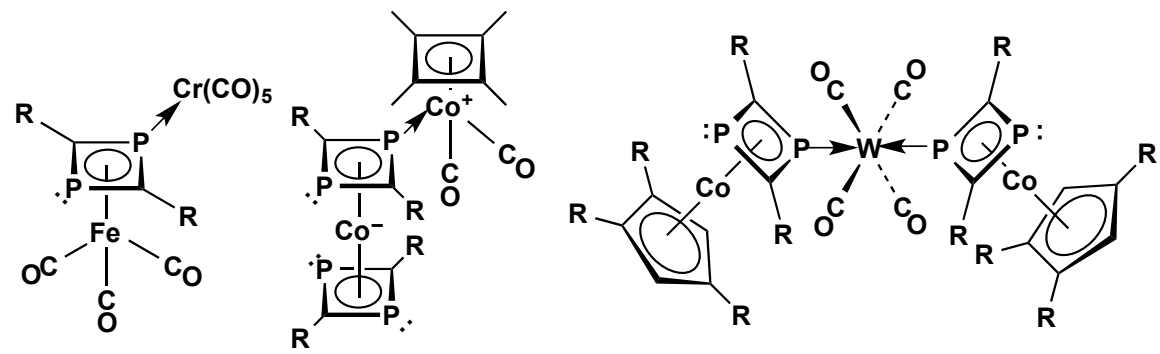

Figure 2. Examples of metal 1,3-diphosphacyclobutadiene complexes functioning as ligands to a second transition metal through a phosphorus lone pair. Typically $\mathrm{R}=$ tert-butyl.

The involvement of the ring phosphorus lone pairs in the 1,3-diphosphacyclobutadiene metal complexes $\left(\mathrm{Me}_{2} \mathrm{C}_{2} \mathrm{P}_{2}\right)_{2} \mathrm{M}_{2}(\mathrm{CO})_{n}(\mathrm{M}=\mathrm{Fe}$ [17], $\mathrm{Mn}$ [18]) of iron and manganese makes the corresponding cobalt derivatives $\left(\mathrm{Me}_{2} \mathrm{C}_{2} \mathrm{P}_{2}\right)_{2} \mathrm{Co}_{2}(\mathrm{CO})_{n}$ of interest. This is particularly true since previous studies on the binuclear phospholyl cobalt carbonyls $\left(\mathrm{C}_{4} \mathrm{H}_{4} \mathrm{P}\right)_{2} \mathrm{Co}_{2}(\mathrm{CO})_{n}$ suggested lack of involvement of the phosphorus lone pairs in the lowenergy structures. This is similar to the iron derivatives $\left(\mathrm{C}_{4} \mathrm{H}_{4} \mathrm{P}\right)_{2} \mathrm{Fe}_{2}(\mathrm{CO})_{n}$ [5] but different from the corresponding manganese derivatives $\left(\mathrm{C}_{4} \mathrm{H}_{4} \mathrm{P}\right)_{2} \mathrm{Mn}_{2}(\mathrm{CO})_{n}$ [4]. Thus the lowest energy $\left(\mathrm{C}_{4} \mathrm{H}_{4} \mathrm{P}\right)_{2} \mathrm{Co}_{2}(\mathrm{CO})_{n}$ structures have terminal phospholyl rings and are analogous to the corresponding cyclopentadienyl cobalt carbonyls $\left(\mathrm{C}_{5} \mathrm{H}_{5}\right)_{2} \mathrm{Co}_{2}(\mathrm{CO})_{n}$ lacking ring phosphorus atoms.

This paper reports a density functional theory study of the structures and thermochemistry of the 1,3-diphosphacyclobutadiene derivatives $\left(\mathrm{Me}_{2} \mathrm{C}_{2} \mathrm{P}_{2}\right)_{2} \mathrm{Co}_{2}(\mathrm{CO})_{n}(n=$ $5,4,3,2)$. Methyl substituents on the carbon atoms were chosen to provide the simplest systems computationally to model potentially accessible structures. However, no $\left(\mathrm{R}_{2} \mathrm{C}_{2} \mathrm{P}_{2}\right)_{2} \mathrm{Co}_{2}(\mathrm{CO})_{n}$ derivatives have been synthesized, even with the tert-butyl substituents found in the very stable iron complex $\left(\mathrm{tBu}_{2} \mathrm{C}_{2} \mathrm{P}_{2}\right) \mathrm{Fe}(\mathrm{CO})_{3}$. Nevertheless, the related binuclear tetramethylcyclobutadiene cobalt carbonyl derivative $\left(\eta^{4}-\mathrm{Me}_{4} \mathrm{C}_{4}\right)_{2} \mathrm{Co}_{2}(\mathrm{CO})_{4}$ has 
been synthesized in relatively low yield and characterized by elemental analysis, mass spectrometry, and infrared $v(\mathrm{CO})$ frequencies [21]. It is presumed to have a trans doubly bridged structure based on its infrared $v(\mathrm{CO})$ frequencies. However, this has not been confirmed by X-ray crystallography.

\section{Theoretical Methods}

Electron correlation effects were considered by employing density functional theory (DFT) methods, which have evolved as a practical and effective computational tool, especially for organometallic compounds [22, 23, 24, 25, 26, 27, 28]. Thus two DFT functionals were used in this study. The first method uses the B3LYP functional, which is the hybrid HF/DFT functional combining the three-parameter Becke functional with the Lee-Yang-Parr generalized gradient correlation functional [29, 30]. The other DFT method used in the present paper is BP86, which combines Becke's 1988 exchange functional with Perdew's 1986 gradient corrected correlation functional [31, 32]. The B3LYP and BP86 methods agree with each other fairly well in the present study in predicting the structural characteristics of the $\left(\mathrm{Me}_{2} \mathrm{C}_{2} \mathrm{P}\right)_{2} \mathrm{Co}_{2}(\mathrm{CO})_{n}$ derivatives of interest. The BP86 vibrational frequencies have been shown to be closer to the experimental results without scaling factors [33, 34]. This concurrence may be accidental, since the theoretical vibrational frequencies predicted by BP86 are harmonic frequencies, whereas the experimental fundamental frequencies are anharmonic. Anyway, the BP86 frequencies are those reported in the text.

All computations were performed using the double- $\zeta$ plus polarization (DZP) basis sets. The DZP basis sets used for carbon, oxygen and phosphorus add one set of pure spherical harmonic $d$ functions with orbital exponents $\alpha_{d}(C)=0.75, \alpha_{d}(O)=0.85$ and $\alpha_{d}(P)$ $=0.60$ to the standard Huzinaga-Dunning contracted DZ sets $[35,36]$. For hydrogen, a set of p polarization functions $\alpha_{\mathrm{p}}(\mathrm{H})=0.75$ is added to the Huzinaga-Dunning DZ set. The loosely contracted DZP basis set for cobalt is the Wachters primitive set [37] augmented by two sets of $\mathrm{p}$ functions and a set of $\mathrm{d}$ functions, contracted following Hood, Pitzer, and Schaefer [38], and designated as (14s11p6d/10s8p3d). We have used the DZP basis sets extensively in our previous research and have a good sense of its strengths and weaknesses. We are not aware of any systematic studies showing that larger basis sets yield more accurate DFT predictions.

The geometries of all structures were fully optimized. The vibrational frequencies and the corresponding infrared intensities were determined analytically. All of the computations were carried out with the Gaussian 09 program [39], exercising the fine grid option (75 radial shells, 302 angular points) for evaluating integrals numerically [40]. For 
the closed-shell (singlet) structures the spin restricted approach is excised, while for the open-shell (triplet) structures the unrestricted approach is adopted. The spin contamination for all triplet structures in the present paper is negligible $(<2.11)$.

\section{Results}

\subsection{Molecular Structures.}

3.1.1. $\left(\mathrm{Me}_{2} \mathrm{C}_{2} \mathrm{P}_{2}\right)_{2} \mathrm{Co}_{2}(\mathrm{CO})_{5}$. Five low-energy singlet structures were found for $\left(\mathrm{Me}_{2} \mathrm{C}_{2} \mathrm{P}_{2}\right)_{2} \mathrm{Co}_{2}(\mathrm{CO})_{5}$ (Figure 3 and Tables 1 and 2). Triplet structures were also explored. However, their energies were found to be much higher than the lowest-energy structure by $30 \mathrm{kcal} / \mathrm{mol}$, so they are not discussed in the present paper. The lowest energy $\left(\mathrm{Me}_{2} \mathrm{C}_{2} \mathrm{P}_{2}\right)_{2} \mathrm{Co}_{2}(\mathrm{CO})_{5}$ structure 5S-1 has five terminal $\mathrm{CO}$ groups, a terminal $\eta^{4}-\mathrm{C}_{2} \mathrm{P}_{2}$ ring, and a bridging non-planar $\eta^{1}, \eta^{3}-\mathrm{C}_{2} \mathrm{P}_{2}$ ring. The long $\mathrm{Co} \cdots \mathrm{Co}$ distance of $\sim 4.4 \AA$ suggests the absence of a direct cobalt-cobalt bond. Nevertheless each cobalt atom in $\mathbf{5 S - 1}$ has the favored 18-electron configuration.

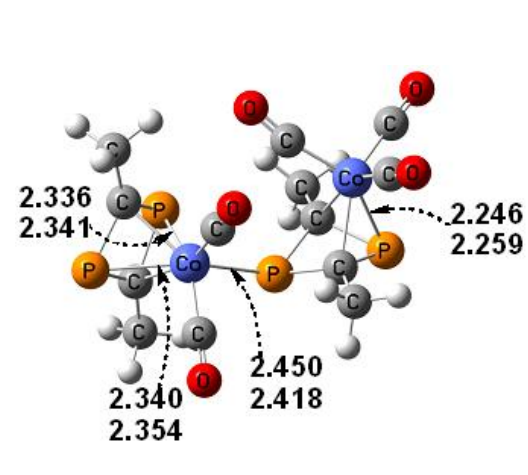

5S-1 $\left(C_{1}\right)$

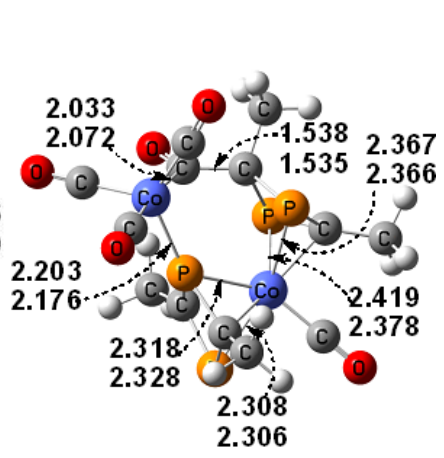

$5 \mathrm{~S}-2\left(C_{1}\right)$
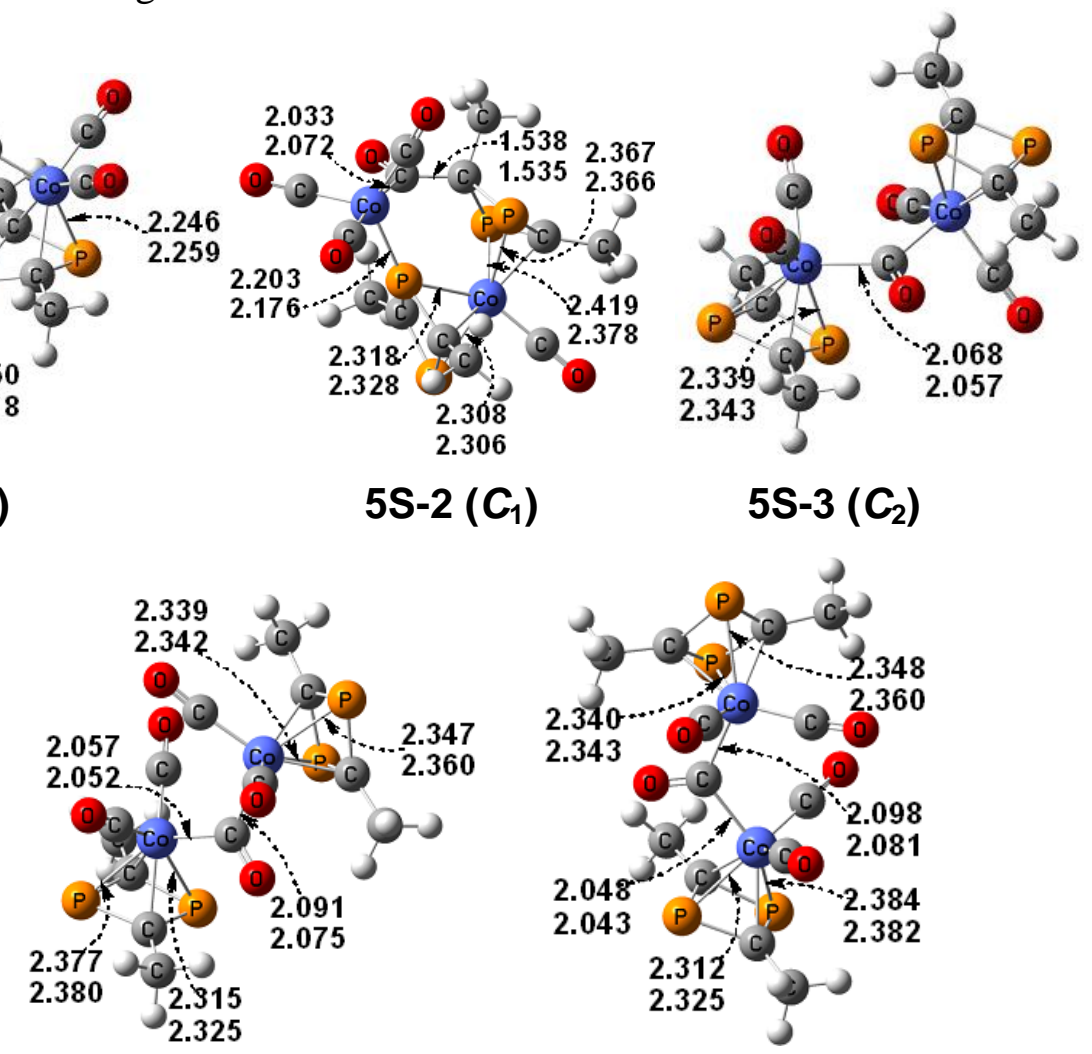

5S-4 $\left(C_{1}\right)$

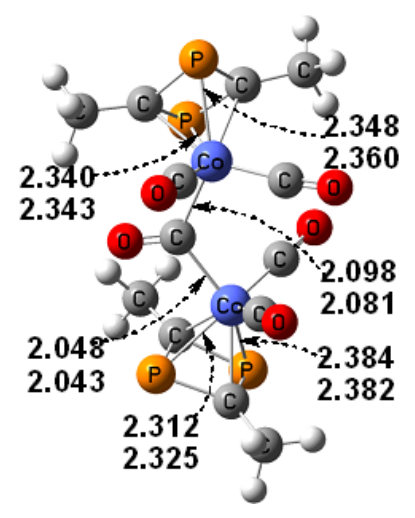

$5 S-5\left(C_{1}\right)$

Figure 3. The optimized $\left(\mathrm{Me}_{2} \mathrm{C}_{2} \mathrm{P}_{2}\right)_{2} \mathrm{Co}_{2}(\mathrm{CO})_{5}$ structures with their symmetry point groups in parentheses. The bond distances are in $\AA$, and the upper numbers are B3LYP distances, while the lower numbers are BP86 distances. 
Table 1. Total energies ( $E$, in hartree), relative energies $(\Delta E$, in $\mathrm{kcal} / \mathrm{mol})$, and Co-Co distances $(\AA)$, for the three stationary points of $\left(\mathrm{Me}_{2} \mathrm{C}_{2} \mathrm{P}_{2}\right)_{2} \mathrm{Co}_{2}(\mathrm{CO})_{5}$. None of these structures has any imaginary vibrational frequencies.

\begin{tabular}{|c|c|c|c|c|c|}
\hline & $\begin{array}{c}\mathbf{5 S - 1} \\
\left(\mathrm{C}_{1},{ }^{1} \mathrm{~A}\right)\end{array}$ & $\begin{array}{c}\mathbf{5 S - 2} \\
\left(\mathrm{C}_{1},{ }^{1} \mathrm{~A}\right)\end{array}$ & $\begin{array}{c}\mathbf{5 S - 3} \\
\left(\mathrm{C}_{2},{ }^{1} \mathrm{~A}\right)\end{array}$ & $\begin{array}{c}5 \mathrm{SS}-\mathbf{4} \\
\left(\mathrm{C}_{1},{ }^{1} \mathrm{~A}\right)\end{array}$ & $\begin{array}{c}\mathbf{5 S}-\mathbf{5} \\
\left(\mathrm{C}_{1},{ }^{1} \mathrm{~A}\right)\end{array}$ \\
\hline \multicolumn{6}{|l|}{ B3LYP } \\
\hline$-\mathrm{E}$ & 5009.96743 & 5009.95693 & 5009.95917 & 5009.95565 & 5009.95408 \\
\hline$\Delta \mathrm{E}$ & 0.0 & 6.6 & 5.2 & 7.4 & 8.4 \\
\hline Co-Co & 4.414 & 4.080 & 3.652 & 3.642 & 3.631 \\
\hline \multicolumn{6}{|l|}{ BP86 } \\
\hline$-\mathrm{E}$ & 5010.58111 & 5010.57626 & 5010.57317 & 5010.57009 & 5010.56872 \\
\hline$\Delta \mathrm{E}$ & 0.0 & 3.0 & 5.0 & 6.9 & 7.8 \\
\hline Co-Co & 4.369 & 4.099 & 3.600 & 3.597 & 3.587 \\
\hline
\end{tabular}

Table 2. Harmonic $v(\mathrm{CO})$ vibrational frequencies (in $\mathrm{cm}^{-1}$ ) predicted for the three $\left(\mathrm{Me}_{2} \mathrm{C}_{2} \mathrm{P}_{2}\right)_{2} \mathrm{Co}_{2}(\mathrm{CO})_{5}$ structures. Infrared intensities (in $\mathrm{km} / \mathrm{mol}$ ) are in parentheses. Those frequencies for the bridging $\mathrm{CO}$ groups are in bold face.

\begin{tabular}{|c|c|}
\hline & BP86 \\
\hline 5S-1 & 1967(393), 1978(522), 1991(381), 2002(796), 2033(875) \\
\hline 5S-2 & 1687(207), 1970(844), 1974(575), 1991(648), 2032(872) \\
\hline 5S-3 & 1720(165), 1967(52), 1982(840), 2007(1094), 2017(1) \\
\hline 5S-4 & 1726(163), 1971(212), 1980(486), 1998(416), 2022(884) \\
\hline 5S-5 & 1724(159), 1972(173), 1977(502), 1996(430), 2021(806) \\
\hline
\end{tabular}

The $\left(\mathrm{Me}_{2} \mathrm{C}_{2} \mathrm{P}_{2}\right)_{2} \mathrm{Co}_{2}(\mathrm{CO})_{5}$ structure 5S-2, lying $6.6 \mathrm{kcal} / \mathrm{mol}$ (B3LYP) or $3.0 \mathrm{kcal} / \mathrm{mol}$ (BP86) in energy above $\mathbf{5 S - 1}$, has four normal terminal CO groups with three on one cobalt atom and the fourth terminal $\mathrm{CO}$ group on the other cobalt atom (Figure 3 and Table 1). The fifth $\mathrm{CO}$ group abnormally bridges the cobalt atom bearing three terminal $\mathrm{CO}$ groups to the carbon atom in the $\eta^{1}, \eta^{3}-\mathrm{Me}_{2} \mathrm{C}_{2} \mathrm{P}_{2}$ ring. This ligand also donates three electrons to the cobalt atom bearing only one terminal $\mathrm{CO}$ group. The other $\eta^{1}, \eta^{4}-\mathrm{Me}_{2} \mathrm{C}_{2} \mathrm{P}_{2}$ ligand bridges the cobalt atoms as a tetrahapto ligand to one cobalt atom and by a $\mathrm{P} \rightarrow$ Co dative bond to the other cobalt atom. As in $\mathbf{5 S - 1}$, the long Co ${ }^{\cdots C}$ Co distance of $\sim 4.1 \AA$ in $\mathbf{5 S - 2}$ suggests the absence of a direct cobalt-cobalt bond. Nevertheless each cobalt atom in 5S-2 has the favored 18-electron configuration.

The $C_{2}\left(\mathrm{Me}_{2} \mathrm{C}_{2} \mathrm{P}_{2}\right)_{2} \mathrm{Co}_{2}(\mathrm{CO})_{5}$ structure $5 \mathrm{~S}-3$, lying $5.2 \mathrm{kcal} / \mathrm{mol}$ (B3LYP) or $5.0 \mathrm{kcal} / \mathrm{mol}$ (BP86) in energy above 5S-1, has four terminal CO groups, a bridging CO group, and two terminal $\eta^{4}-\mathrm{Me}_{2} \mathrm{C}_{2} \mathrm{P}_{2}$ ligands (Figure 3 and Table 1). The terminal $\mathrm{CO}$ groups are distributed evenly between the two cobalt atoms. The very long Co ${ }^{\cdots C} \mathrm{Co}$ distance 
of $\sim 5 \AA$ suggests the lack of a direct cobalt-cobalt bond. The two $\left(\mathrm{Me}_{2} \mathrm{C}_{2} \mathrm{P}_{2}\right) \mathrm{Co}(\mathrm{CO})_{2}$ units are connected solely by the bridging $\mathrm{CO}$ group. Thus $\mathbf{5 S - 3}$ provides a rare example of a binuclear metal carbonyl structure linked solely by a bridging $\mathrm{CO}$ group without an accompanying metal-metal bond. The $\left(\mathrm{Me}_{2} \mathrm{C}_{2} \mathrm{P}_{2}\right)_{2} \mathrm{Co}_{2}(\mathrm{CO})_{5}$ structures 5S-4 and 5S-5, lying 7.4 and $8.4 \mathrm{kcal} / \mathrm{mol}$ (B3LYP) or 6.9 and $7.8 \mathrm{kcal} / \mathrm{mol}$ (BP86), respectively, in energy above $\mathbf{5 S - 1}$, have similar geometries to that of $\mathbf{5 S - 3}$, differing only by the relative positions of the $\left(\mathrm{Me}_{2} \mathrm{C}_{2} \mathrm{P}_{2}\right) \mathrm{Co}(\mathrm{CO})_{2}$ units and the terminal $\mathrm{CO}$ ligands. Each cobalt atom in all three structures $\mathbf{5 S - 3}, \mathbf{5 S - 4}$, and $\mathbf{5 S - 5}$ has the favored 18-electron configuration despite the absence of direct cobalt-cobalt bonds.

Table 2 summarizes the theoretical $v(\mathrm{CO})$ frequencies for the five $\left(\mathrm{Me}_{2} \mathrm{C}_{2} \mathrm{P}_{2}\right)_{2} \mathrm{Co}_{2}(\mathrm{CO})_{5}$ structures. The $\square(\mathrm{CO})$ frequencies for the bridging $\mathrm{CO}$ groups in structures 5S-2, 5S-3, 5S-4, and 5S-5 range from 1687 to $1724 \mathrm{~cm}^{-1}$ These frequencies are much lower than those of the normal bridging $\mathrm{CO}$ groups bridging a $\mathrm{Co}-\mathrm{Co}$ bond. In 5S-3, 5S-4, and 5S-5 these CO groups bridge two cobalt atoms that are too far apart to form a Co-Co bond. In $\mathbf{5 S - 2}$ the bridging $\mathrm{CO}$ group connects a cobalt atom to a carbon atom in a $\mathrm{C}_{2} \mathrm{P}_{2}$ ring. The $\square(\mathrm{CO})$ frequencies for the terminal $\mathrm{CO}$ groups in the $\left(\mathrm{Me}_{2} \mathrm{C}_{2} \mathrm{P}_{2}\right)_{2} \mathrm{Co}_{2}(\mathrm{CO})_{5}$ structures fall in the normal regions, ranging from 1967 to $2033 \mathrm{~cm}^{-1}$.

3.1.2. $\left(\mathrm{Me}_{2} \mathrm{C}_{2} \mathrm{P}_{2}\right)_{2} \mathrm{Co}_{2}(\mathrm{CO})_{4}$. Five low-energy $\left(\mathrm{Me}_{2} \mathrm{C}_{2} \mathrm{P}_{2}\right)_{2} \mathrm{Co}_{2}(\mathrm{CO})_{4}$ structures (four singlet and one triplet structures) were found for (Figure 4 and Tables 3 and 4). The lowest energy structure 4S-1 $\left(C_{s}\right)$ has four symmetrically distributed terminal $\mathrm{CO}$ groups, one bridging $\eta^{1}, \eta^{4}-\mathrm{Me}_{2} \mathrm{C}_{2} \mathrm{P}_{2}$ ligand, and one bridging $\eta^{1}, \eta^{3}-\mathrm{Me}_{2} \mathrm{C}_{2} \mathrm{P}_{2}$ ligand. The long $\mathrm{Co}{ }^{\cdots} \mathrm{Co}$ distance of $3.862 \AA$ (B3LYP) or $3.850 \AA$ (BP86) suggests the absence of a direct bond. Nevertheless, each cobalt atom has the favored 18-electron configuration.

The $\left(\mathrm{Me}_{2} \mathrm{C}_{2} \mathrm{P}_{2}\right)_{2} \mathrm{Co}_{2}(\mathrm{CO})_{4}$ structures 4S-2 $\left(C_{2}\right)$ and 4S-3 $\left(C_{i}\right)$, lying 7.2 and $7.6 \mathrm{kcal} / \mathrm{mol}$ (B3LYP) or 3.1 and $3.5 \mathrm{kcal} / \mathrm{mol}$ (BP86), respectively, in energy above $\mathbf{4 S - 1}$, have similar geometries (Figure 4 and Table 3). Both 4S-2 and 4S-3 have two terminal CO groups, two bridging $\mathrm{CO}$ groups, and two terminal $\eta^{4}-\mathrm{Me}_{2} \mathrm{C}_{2} \mathrm{P}_{2}$ ligands. Structures $\mathbf{4 S - 2}$ and 4S-3 differ only in the relative orientation of the two $\eta^{4}-\mathrm{Me}_{2} \mathrm{C}_{2} \mathrm{P}_{2}$ ligands. The Co-Co distances of 2.537 and $2.536 \AA$ (B3LYP) or 2.505 and $2.504 \AA$ (BP86) in 4S-2 and 4S-3, respectively, suggest formal single bonds. This gives each cobalt atom in $\mathbf{4 S - 2}$ and $\mathbf{4 S - 3}$ the favored 18-electron configuration.

The $C_{2 h}\left(\mathrm{Me}_{2} \mathrm{C}_{2} \mathrm{P}_{2}\right)_{2} \mathrm{Co}_{2}(\mathrm{CO})_{4}$ structure 4S-4, lying $5.1 \mathrm{kcal} / \mathrm{mol}$ (B3LYP) or $9.3 \mathrm{kcal} / \mathrm{mol}$ (BP86) in energy above $\mathbf{4 S - 1}$, has four symmetrically distributed terminal CO groups and two terminal $\eta^{4}-\mathrm{Me}_{2} \mathrm{C}_{2} \mathrm{P}_{2}$ ligands (Figure 4 and Table 3). The Co-Co distance in 4S-4 is predicted to be $2.762 \AA$ (B3LYP) or $2.731 \AA$ (BP86), suggesting a formal Co-Co 
single bond, thereby giving each cobalt atom the favored 18-electron configuration. The longer Co-Co bond in $\mathbf{4 S - 4}$ by $\sim 0.2 \AA$ relative to $\mathbf{4 S - 2}$ and $\mathbf{4 S - 3}$ relates to the absence of bridging $\mathrm{CO}$ groups in $\mathbf{4 S - 4}$ as compared with the presence of two bridging $\mathrm{CO}$ groups in both $4 \mathrm{~S}-2$ and $4 \mathrm{~S}-3$.

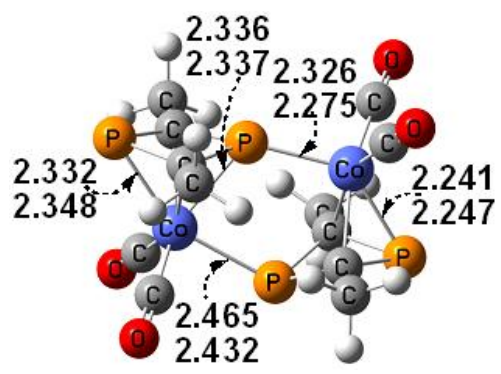

4S-1 $\left(C_{s}\right)$

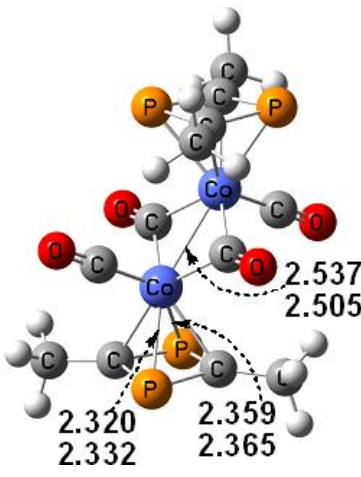

4S-2 $\left(C_{2}\right)$

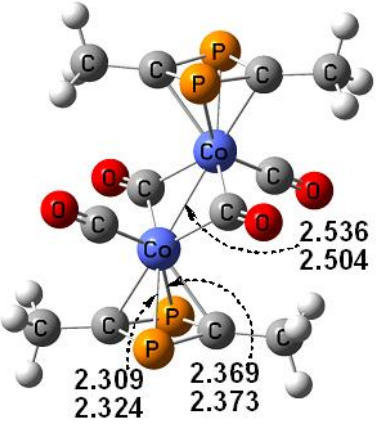

4S-3 $\left(C_{i}\right)$

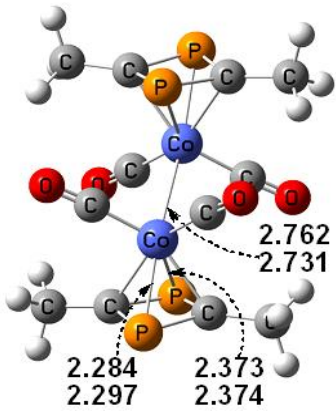

4S-4 $\left(C_{2 h}\right)$

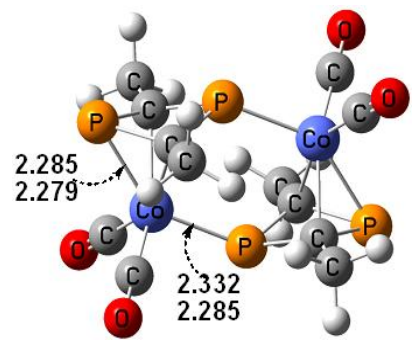

4T-1 $\left(C_{2 h}\right)$

Figure 4. The optimized $\left(\mathrm{Me}_{2} \mathrm{C}_{2} \mathrm{P}_{2}\right)_{2} \mathrm{Co}_{2}(\mathrm{CO})_{4}$ structures with their symmetry point groups in parentheses.

Table 3. Total energies ( $E$, in hartree), relative energies ( $\Delta E$, in $\mathrm{kcal} / \mathrm{mol})$, Co-Co distances $(\AA)$, and spin expectation values $\left\langle\mathrm{S}^{2}\right\rangle$ for the $\left(\mathrm{Me}_{2} \mathrm{C}_{2} \mathrm{P}_{2}\right)_{2} \mathrm{Co}_{2}(\mathrm{CO})_{4}$ structures. None of these structures has any imaginary vibrational frequencies.

\begin{tabular}{|c|c|c|c|c|c|}
\hline & $\begin{array}{c}\mathbf{4 S - 1} \\
\left(\mathrm{C}_{\mathrm{s}},{ }^{1} \mathrm{~A}^{\prime}\right)\end{array}$ & $\begin{array}{c}\mathbf{4 S - 2} \\
\left(\mathrm{C}_{2},{ }^{1} \mathrm{~A}\right)\end{array}$ & $\begin{array}{c}4 \mathrm{~S}-3 \\
\left(\mathrm{C}_{\mathrm{i}},{ }^{1} \mathrm{~A}_{\mathrm{g}}\right)\end{array}$ & $\begin{array}{c}\mathbf{4 S - 4} \\
\left(\mathrm{C}_{2 \mathrm{~h}},{ }^{1} \mathrm{~A}_{\mathrm{g}}\right)\end{array}$ & $\begin{array}{c}\text { 4T-1 } \\
\left(\mathrm{C}_{2 \mathrm{~h}},{ }^{3} \mathrm{~B}_{\mathrm{u}}\right)\end{array}$ \\
\hline \multicolumn{6}{|c|}{ B3LYP } \\
\hline$-\mathrm{E}$ & 4896.63487 & 4896.62332 & 4896.62270 & 4896.62674 & 4896.60595 \\
\hline$\Delta \mathrm{E}$ & 0.0 & 7.2 & 7.6 & 5.1 & 18.1 \\
\hline $\mathrm{Co}-\mathrm{Co}$ & 3.862 & 2.537 & 2.536 & 2.762 & 3.861 \\
\hline$\left\langle\mathrm{S}^{2}\right\rangle$ & 0.00 & 0.00 & 0.00 & 0.00 & 2.08 \\
\hline \multicolumn{6}{|l|}{ BP86 } \\
\hline$-\mathrm{E}$ & 4897.24342 & 4897.23846 & 4897.23780 & 4897.22865 & 4897.21056 \\
\hline$\Delta \mathrm{E}$ & 0.0 & 3.1 & 3.5 & 9.3 & 20.6 \\
\hline $\mathrm{Co}-\mathrm{Co}$ & 3.850 & 2.505 & 2.504 & 2.731 & 3.864 \\
\hline$\left\langle\mathbf{S}^{2}\right\rangle$ & 0.00 & 0.00 & 0.00 & 0.00 & 2.01 \\
\hline
\end{tabular}


The $C_{2 h}$ triplet $\left(\mathrm{Me}_{2} \mathrm{C}_{2} \mathrm{P}_{2}\right)_{2} \mathrm{Co}_{2}(\mathrm{CO})_{4}$ structure 4T-1, lying at the relatively high energy of $18.1 \mathrm{kcal} / \mathrm{mol}$ (B3LYP) or $20.6 \mathrm{kcal} / \mathrm{mol}$ (BP86) above $\mathbf{4 S - 1}$, has four symmetrically distributed terminal $\mathrm{CO}$ groups and two bridging $\eta^{1}, \eta^{3}-\mathrm{Me}_{2} \mathrm{C}_{2} \mathrm{P}_{2}$ ligands (Figure 4 and Table 3). The long Co ${ }^{\cdots}$ Co distance of $3.861 \AA$ (B3LP) or $3.864 \AA$ (BP86), suggests the absence of a direct bond. The $\eta^{1}, \eta^{3}-\mathrm{Me}_{2} \mathrm{C}_{2} \mathrm{P}_{2}$ ligands donate three electrons to one cobalt atom and one electron to the other Co atom. Thus each cobalt atom has a 17-electron configuration, consistent with a binuclear triplet.

The $v(\mathrm{CO})$ frequencies for the bridging $\mathrm{CO}$ groups in $\mathbf{4 S - 2}$ and $4 \mathrm{~S}-3$ range from 1825 to $1857 \mathrm{~cm}^{-1}$ (Table 4). The $v(\mathrm{CO})$ frequencies for the terminal $\mathrm{CO}$ groups, ranging from 1953 to $2014 \mathrm{~cm}^{-1}$, are significantly higher than those of the bridging $\mathrm{CO}$ groups as expected.

Table 4. Harmonic $v(\mathrm{CO})$ vibrational frequencies (in $\mathrm{cm}^{-1}$ ) predicted for the five $\left(\mathrm{Me}_{2} \mathrm{C}_{2} \mathrm{P}_{2}\right)_{2} \mathrm{Co}_{2}(\mathrm{CO})_{4}$ structures. Infrared intensities (in $\mathrm{km} / \mathrm{mol}$ ) are in parentheses. Those frequencies for the bridging $\mathrm{CO}$ groups are in bold face.

\begin{tabular}{|c|c|}
\hline & BP86 \\
\hline 4S-1 & 1970(476), 1980(700), 2000(1676), 2014(121) \\
\hline 4S-2 & 1825(549), 1857(88), 1983(1001), 1992(2) \\
\hline $4 S-3$ & 1828(638), 1852(0), 1981(1008), 1991(0) \\
\hline 4S-4 & 1953(0), 1965(1047), 1972(709), 1996(0) \\
\hline $4 \mathrm{~T}-1$ & 1971(0), 1974(1192), 1994(2070), 2008(0) \\
\hline
\end{tabular}

3.1.3. $\left(\mathrm{Me}_{2} \mathrm{C}_{2} \mathrm{P}_{2}\right)_{2} \mathrm{Co}_{2}(\mathrm{CO})_{3}$. Five low-energy singlet structures were found for the tricarbonyl $\left(\mathrm{Me}_{2} \mathrm{C}_{2} \mathrm{P}_{2}\right)_{2} \mathrm{Co}_{2}(\mathrm{CO})_{3}$ (Figure 5 and Tables 5 and 6). The lowest energy triplet $\left(\mathrm{Me}_{2} \mathrm{C}_{2} \mathrm{P}_{2}\right)_{2} \mathrm{Co}_{2}(\mathrm{CO})_{3}$ structure lies $\sim 10 \mathrm{kcal} / \mathrm{mol}$ in energy above the lowest energy singlet structure 3S-1 suggesting limited chemical significance of triplet $\left(\mathrm{Me}_{2} \mathrm{C}_{2} \mathrm{P}_{2}\right)_{2} \mathrm{Co}_{2}(\mathrm{CO})_{3}$ structures, which therefore are not discussed in this paper. Structure 3S-1 has three terminal $\mathrm{CO}$ groups (two on one cobalt atom and one on the other cobalt atom), one terminal $\eta^{4}-\mathrm{C}_{2} \mathrm{P}_{2}$ ring on the cobalt atom bearing one $\mathrm{CO}$ group, and one bridging $\eta^{1}, \eta^{4}-\mathrm{C}_{2} \mathrm{P}_{2}$ ring. The $\eta^{1}, \eta^{4}-C_{2} P_{2}$ ring is a tetrahapto ligand to one cobalt atom and one of its phosphorus atoms donate its lone pair to the other cobalt atom with a dative $\mathrm{P} \rightarrow \mathrm{Co}$ bond. Thus this $\eta^{1}, \eta^{4}-\mathrm{C}_{2} \mathrm{P}_{2}$ ring is a six-electron donor to the central $\mathrm{Co}_{2}$ unit The Co-Co distance of $2.786 \AA$ (B3LYP) or $2.758 \AA$ (BP86) in 3S-1 suggests a formal single bond thereby giving each cobalt atom the favored 18 -electron configuration.

The $\left(\mathrm{Me}_{2} \mathrm{C}_{2} \mathrm{P}_{2}\right)_{2} \mathrm{Co}_{2}(\mathrm{CO})_{3}$ structure 3S-2, lying $4.9 \mathrm{kcal} / \mathrm{mol}$ (B3LYP) or $1.7 \mathrm{kcal} / \mathrm{mol}$ (BP86) in energy above 3S-1, has three terminal $\mathrm{CO}$ groups (two on one 
cobalt atom and one on the other cobalt atom) and one bridging $\eta^{1}, \eta^{4}-\mathrm{Me}_{2} \mathrm{C}_{2} \mathrm{P}_{2}$ ligand (Figure 5 and Table 5). The other $\eta^{4}-\mathrm{C}_{2} \mathrm{P}_{2}$ ring is opened by insertion of a cobalt atom into a $\mathrm{P}-\mathrm{C}$ bond so that the resulting PCPC chain donates six electrons to the central $\mathrm{Co}_{2}$ unit. The Co-Co distance of $2.590 \AA$ Á (B3LYP) or $2.580 \AA$ (BP86) suggests the formal single bond required to give each cobalt atom the favored 18-electron configurations.

The $C_{2}\left(\mathrm{Me}_{2} \mathrm{C}_{2} \mathrm{P}_{2}\right)_{2} \mathrm{Co}_{2}(\mathrm{CO})_{3}$ structure 3S-3, lying $13.6 \mathrm{kcal} / \mathrm{mol}$ (B3LYP) or $6.0 \mathrm{kcal} / \mathrm{mol}$ (BP86) in energy above 3S-1, has one bridging $\mathrm{CO}$ group, two terminal $\mathrm{CO}$ groups, a bridging $\eta^{1}, \eta^{4}-\mathrm{C}_{2} \mathrm{P}_{2}$ ring, and a terminal $\eta^{4}-\mathrm{Me}_{2} \mathrm{C}_{2} \mathrm{P}_{2}$ ligand (Figure 5 and Table 5). One phosphorus atom in the $\eta^{1}, \eta^{4}-\mathrm{Me}_{2} \mathrm{C}_{2} \mathrm{P}_{2}$ ligand is linked to the other cobalt atom by a dative $\mathrm{P} \rightarrow \mathrm{Co}$ bond of length $\sim 2.4 \AA$ so that this ligand is a six-electron donor to the central $\mathrm{Co}_{2}$ unit. The Co-Co distance of $2.514 \AA$ (B3LYP) or $2.515 \AA$ (BP86), suggests a formal single bond. This gives each cobalt atom the favored 18-electron configuration, if the Co-Co bond is also a dative bond from the cobalt atom bearing two $\mathrm{CO}$ groups to the cobalt atom bearing a single $\mathrm{CO}$ group.

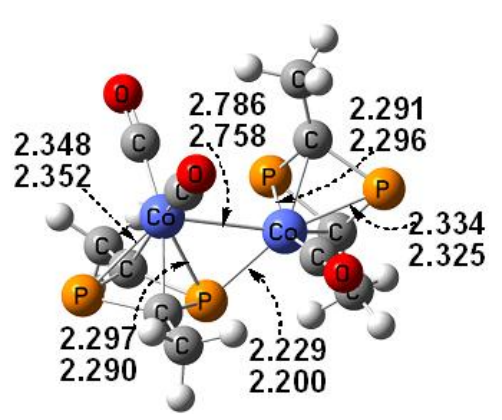

3S-1 $\left(C_{1}\right)$

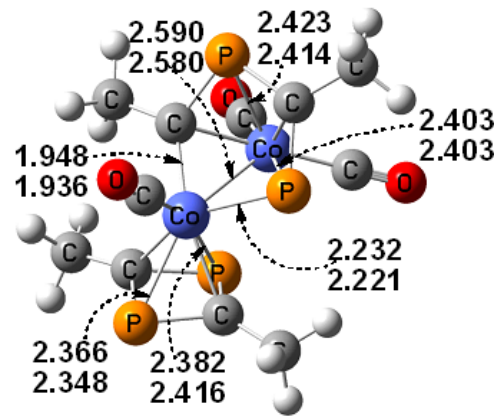

3S-2 $\left(C_{1}\right)$

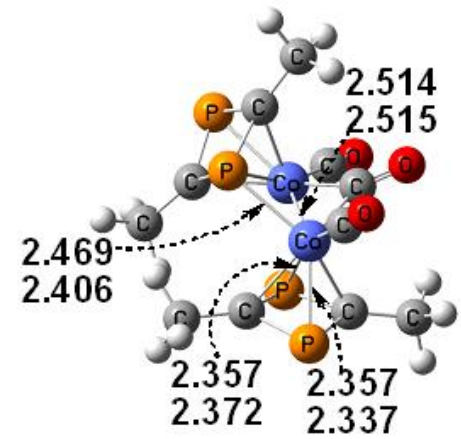

3S-3 $\left(C_{2}\right)$
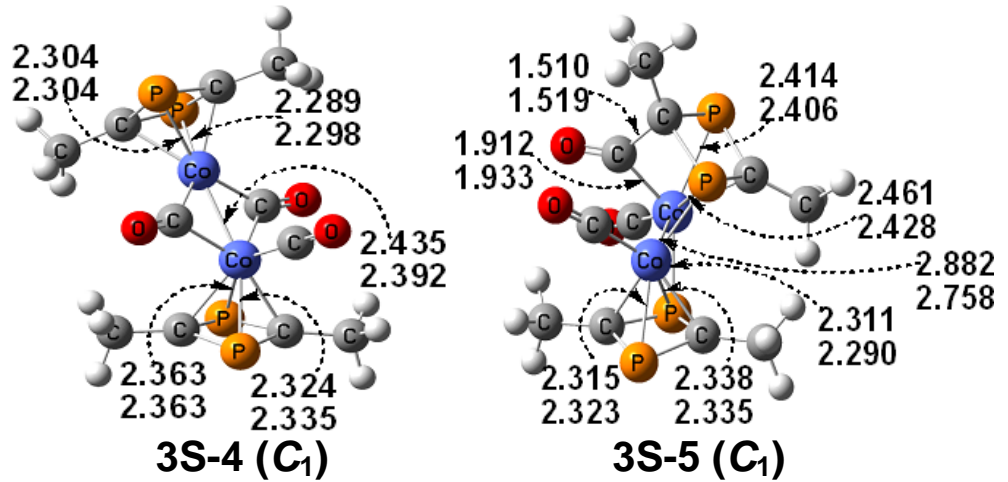

Figure 5. The optimized $\left(\mathrm{Me}_{2} \mathrm{C}_{2} \mathrm{P}_{2}\right)_{2} \mathrm{Co}_{2}(\mathrm{CO})_{3}$ structures with symmetry point groups in parentheses. 
The $\left(\mathrm{Me}_{2} \mathrm{C}_{2} \mathrm{P}_{2}\right)_{2} \mathrm{Co}_{2}(\mathrm{CO})_{3}$ structure 3S-4, lying $23.1 \mathrm{kcal} / \mathrm{mol}$ (B3LYP) or $16.8 \mathrm{kcal} / \mathrm{mol}$ (BP86) above 3S-1, is a relatively high energy structure with two bridging $\mathrm{CO}$ groups, one terminal $\mathrm{CO}$ group, and two terminal $\eta^{4}-\mathrm{Me}_{2} \mathrm{C}_{2} \mathrm{P}_{2}$ ligands (Figure 5 and Table 5) . The $\mathrm{Co}=\mathrm{Co}$ distance in 3S-4 of $2.435 \AA$ (B3LYP) or $2.392 \AA$ (BP86) is $\sim 0.1 \AA$ shorter than the formal $\mathrm{Co}-\mathrm{Co}$ single bonds in the likewise doubly CO-bridged $\left(\mathrm{Me}_{2} \mathrm{C}_{2} \mathrm{P}_{2}\right)_{2} \mathrm{Co}_{2}(\mathrm{CO})_{4}$ structures $\mathbf{4 S - 2}$ and $\mathbf{4 S - 3}$ suggesting a formal double bond in 3S-4. Each cobalt atom in 3S-4 has the favored 18-electron configuration if a formal positive charge is placed on the cobalt atom bearing two $\mathrm{CO}$ groups and a negative charge is placed on the cobalt atom bearing only one terminal $\mathrm{CO}$ group.

The $\left(\mathrm{Me}_{2} \mathrm{C}_{2} \mathrm{P}_{2}\right)_{2} \mathrm{Co}_{2}(\mathrm{CO})_{3}$ structure 3S-5 is an even higher energy structure, lying $22.0 \mathrm{kcal} / \mathrm{mol}$ (B3LYP) or $17.0 \mathrm{kcal} / \mathrm{mol}$ (BP86) above 3S-1 (Figure 5 and Table 5). Structure 3S-5 has two evenly distributed terminal $\mathrm{CO}$ groups and a bridging $\eta^{1}, \eta^{4}-\mathrm{Me}_{2} \mathrm{C}_{2} \mathrm{P}_{2}$ ligand. The other $\mathrm{CO}$ group and the other $\mathrm{Me}_{2} \mathrm{C}_{2} \mathrm{P}_{2}$ ligand are coupled by a carbon-carbon single bond of length $\sim 1.51 \AA$, with the resulting $\mathrm{Me}_{2} \mathrm{C}_{2}(\mathrm{CO}) \mathrm{P}_{2}$ moiety donating six electrons to the central $\mathrm{Co}_{2}$ unit. The Co-Co distance of $2.882 \AA$ (B3LYP) or $2.758 \AA$ (BP86) in 3S-5, suggests a formal single bond, thereby giving each cobalt atom the favored 18-electron configuration.

Table 5. Total energies ( $E$, in hartree), relative energies $(\Delta E$, in $\mathrm{kcal} / \mathrm{mol})$, the Co-Co distances $(\AA)$, and spin expectation values $\left\langle\mathrm{S}^{2}\right\rangle$ for the $\left(\mathrm{Me}_{2} \mathrm{C}_{2} \mathrm{P}_{2}\right)_{2} \mathrm{Co}_{2}(\mathrm{CO})_{3}$ structures. None of these structures has any imaginary vibrational frequencies.

\begin{tabular}{|c|c|c|c|c|c|}
\hline & $\begin{array}{c}\text { 3S-1 } \\
\left(\mathrm{C}_{1},{ }^{1} \mathrm{~A}\right) \\
\end{array}$ & $\begin{array}{c}\text { 3S-2 } \\
\left(\mathrm{C}_{1},{ }^{1} \mathrm{~A}\right) \\
\end{array}$ & $\begin{array}{c}\mathbf{3 S}-\mathbf{3} \\
\left(\mathrm{C}_{2},{ }^{1} \mathrm{~A}\right) \\
\end{array}$ & $\begin{array}{c}3 \mathrm{~S}-\mathbf{4} \\
\left(\mathrm{C}_{1},{ }^{1} \mathrm{~A}\right) \\
\end{array}$ & $\begin{array}{c}3 \mathrm{~S}-5 \\
\left(\mathrm{C}_{1},{ }^{1} \mathrm{~A}\right) \\
\end{array}$ \\
\hline \multicolumn{6}{|l|}{ B3LYP } \\
\hline$-E$ & 4783.27718 & 4783.26939 & 4783.25555 & 4783.24032 & 4783.24205 \\
\hline$\Delta \mathrm{E}$ & 0.0 & 4.9 & 13.6 & 23.1 & 22.0 \\
\hline Co-Co & 2.786 & 2.590 & 2.514 & 2.435 & 2.882 \\
\hline \multicolumn{6}{|l|}{ BP86 } \\
\hline$-E$ & 4783.87440 & 4783.87175 & 4783.86490 & 4783.84768 & 4783.84731 \\
\hline$\Delta \mathrm{E}$ & 0.0 & 1.7 & 6.0 & 16.8 & 17.0 \\
\hline Co-Co & 2.758 & 2.580 & 2.515 & 2.392 & 2.758 \\
\hline
\end{tabular}

The $v(\mathrm{CO})$ frequencies for the bridging $\mathrm{CO}$ groups in the singlet $\left(\mathrm{Me}_{2} \mathrm{C}_{2} \mathrm{P}_{2}\right)_{2} \mathrm{Co}_{2}(\mathrm{CO})_{3}$ structures 3S-3 and 3S-4 range from 1818 to $1840 \mathrm{~cm}^{-1}$ (Table 6), The $v(\mathrm{CO})$ frequencies for the terminal CO groups, ranging from 1956 to $2015 \mathrm{~cm}^{-1}$, are $\sim 100 \mathrm{~cm}^{-1}$ higher than those for the bridging $\mathrm{CO}$ groups, as expected. The $v(\mathrm{CO})$ 
frequency for the $\mathrm{CO}$ group coupled with the $\mathrm{Me}_{2} \mathrm{C}_{2} \mathrm{P}_{2}$ ligand in 3S-5 is unusually low at $1737 \mathrm{~cm}^{-1}$.

Table 6. Harmonic $v(\mathrm{CO})$ vibrational frequencies (in $\mathrm{cm}^{-1}$ ) predicted for the eleven isomers of $\left(\mathrm{Me}_{2} \mathrm{C}_{2} \mathrm{P}_{2}\right)_{2} \mathrm{Co}_{2}(\mathrm{CO})_{3}$. Infrared intensities (in $\left.\mathrm{km} / \mathrm{mol}\right)$ are in parentheses. Those frequencies for the bridging $\mathrm{CO}$ groups are in bold face.

\begin{tabular}{|c|c|}
\hline & BP86 \\
\hline 3S-1 & 1956(101), 1965(1017), 2000(799) \\
\hline 3S-2 & 1979(931), 1982(486), 2015(736) \\
\hline 3S-3 & 1821(313), 1979(1351), 1992(488) \\
\hline 3S-4 & 1818(647), 1840(32), 1994(640) \\
\hline $3 S-5$ & 1737(297), 1971(1052), 1987(611) \\
\hline
\end{tabular}

3.1.4 $\left(\mathrm{Me}_{2} \mathrm{C}_{2} \mathrm{P}_{2}\right)_{2} \mathrm{Co}_{2}(\mathrm{CO})_{2}$. The lowest energy $\left(\mathrm{Me}_{2} \mathrm{C}_{2} \mathrm{P}_{2}\right)_{2} \mathrm{Co}_{2}(\mathrm{CO})_{2}$ structure is the $C_{2}$ singlet 2S-1 structure with one terminal $\mathrm{CO}$ group on each cobalt atom and two bridging $\eta^{1}, \eta^{4}-\mathrm{Me}_{2} \mathrm{C}_{2} \mathrm{P}_{2}$ ligands (Figure 6 and Table 7). Each bridging $\eta^{1}, \eta^{4}-\mathrm{Me}_{2} \mathrm{C}_{2} \mathrm{P}_{2}$ ring is bonded to one cobalt atom as a tetrahapto ligand and to the other cobalt atom through a dative $\mathrm{P} \rightarrow$ Co bond thereby functioning as a six-electron donor to the central $\mathrm{Co}_{2}$ unit The Co-Co distance of $2.853 \AA$ Á (B3LYP) or $2.781 \AA$ (BP86), suggests a formal single Co-Co bond thereby giving each cobalt atom the favored 18-electron configuration. Structure $\mathbf{2 S - 1}$ is obviously a very favorable structure since it lies at least $\sim 16 \mathrm{kcal} / \mathrm{mol}$ below the next lowest energy singlet structures. Because of their relatively high energies the remaining singlet $\left(\mathrm{Me}_{2} \mathrm{C}_{2} \mathrm{P}_{2}\right)_{2} \mathrm{Co}_{2}(\mathrm{CO})_{2}$ structures are not discussed in this paper.

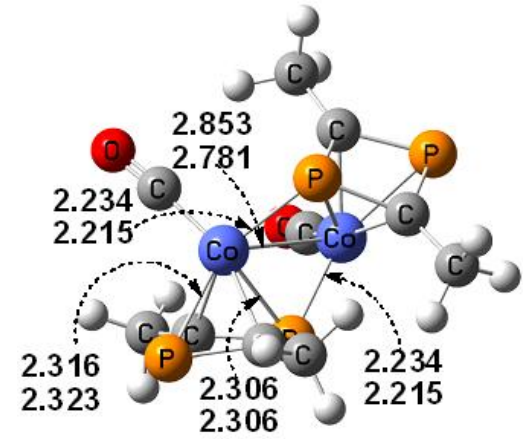

2S-1 $\left(C_{2}\right)$

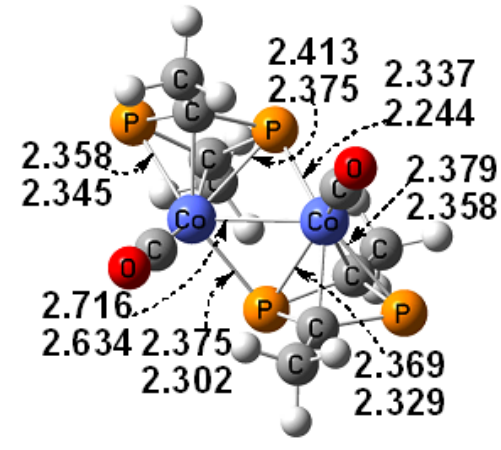

$2 \mathrm{~T}-1\left(C_{1}\right)$

Figure 6. The lowest energy singlet and triplet $\left(\mathrm{Me}_{2} \mathrm{C}_{2} \mathrm{P}_{2}\right)_{2} \mathrm{Co}_{2}(\mathrm{CO})_{2}$ structures with symmetry point groups in parentheses. 
Table 7. Total energies ( $E$, in hartree), relative energies $(\Delta E$, in $\mathrm{kcal} / \mathrm{mol})$ and Co-Co distances $(\AA)$ for the lowest energy singlet and triplet $\left(\mathrm{Me}_{2} \mathrm{C}_{2} \mathrm{P}_{2}\right)_{2} \mathrm{Co}_{2}(\mathrm{CO})_{2}$ structures. Neither structure has any imaginary vibrational frequencies.

\begin{tabular}{ccc}
\hline \hline & $\begin{array}{c}\mathbf{2 S - 1} \\
\left(\mathrm{C}_{2},{ }^{1} \mathrm{~A}\right)\end{array}$ & $\begin{array}{c}\mathbf{2 T - 1} \\
\left(\mathrm{C}_{1},{ }^{3} \mathrm{~A}\right)\end{array}$ \\
\hline B3LYP & & \\
$-\mathrm{E}$ & 4669.90485 & 4669.90338 \\
$\Delta \mathrm{E}$ & 0.0 & 0.9 \\
$\mathrm{Co}-\mathrm{Co}$ & 2.853 & 2.716 \\
$\left\langle\mathrm{~S}^{2}\right\rangle$ & 0.00 & 2.11 \\
\hline BP86 & & \\
$-\mathrm{E}$ & 4670.49748 & 4670.47512 \\
$\Delta \mathrm{E}$ & 0.0 & 14.0 \\
$\mathrm{Co}-\mathrm{Co}$ & 2.781 & 2.634 \\
$\left\langle\mathbf{S}^{2}\right\rangle$ & 0.00 & 2.03 \\
\hline
\end{tabular}

The lowest-energy triplet $\left(\mathrm{Me}_{2} \mathrm{C}_{2} \mathrm{P}_{2}\right)_{2} \mathrm{Co}_{2}(\mathrm{CO})_{2}$ structure $\mathbf{2 T - 1}\left(\mathrm{C}_{1}\right)$ lies $0.9 \mathrm{kcal} / \mathrm{mol}$ (B3LYP) or $14.0 \mathrm{kcal} / \mathrm{mol}$ (BP86) above 2S-1 (Figure 6 and Table 7). Note that the two DFT methods predict different singlet-triplet splittings, which has been thoroughly studied by Reiher and co-workers [41, 42] and more recently reviewed by Harvey [43]. The true singlet-triplet splitting should lie between the B3LYP and BP86 values. The geometry of $\mathbf{2 T - 1}$ is very similar to that of $\mathbf{2 S - 1}$, with a terminal $\mathrm{CO}$ group on each cobalt atom and two bridging $\eta^{1}, \eta^{4}-\mathrm{Me}_{2} \mathrm{C}_{2} \mathrm{P}_{2}$ ligands. The Co-Co distance of $2.716 \AA$ (B3LYP) or $2.634 \AA$ (BP86) is clearly a bonding distance. The remaining triplet $\left(\mathrm{Me}_{2} \mathrm{C}_{2} \mathrm{P}_{2}\right)_{2} \mathrm{Co}_{2}(\mathrm{CO})_{2}$ structures lie at least $\sim 10 \mathrm{kcal} / \mathrm{mol}$ in energy above $\mathbf{2 T - 1}$ and therefore are not discussed in this paper.

The $v(\mathrm{CO})$ frequencies for the terminal $\mathrm{CO}$ groups in the $\left(\mathrm{Me}_{2} \mathrm{C}_{2} \mathrm{P}_{2}\right)_{2} \mathrm{Co}_{2}(\mathrm{CO})_{2}$ structures 2S-1 and 2T-1 range from 1950 to $1977 \mathrm{~cm}^{-1}$ (Table 8), as expected, since there are no bridging $\mathrm{CO}$ groups in the two structures.

Table 8. Harmonic $v(\mathrm{CO})$ vibrational frequencies (in $\mathrm{cm}^{-1}$ ) predicted for the $\left(\mathrm{Me}_{2} \mathrm{C}_{2} \mathrm{P}_{2}\right)_{2} \mathrm{Co}_{2}(\mathrm{CO})_{2}$ structures. Infrared intensities (in $\mathrm{km} / \mathrm{mol}$ ) are in parentheses.

\begin{tabular}{lc}
\hline \hline & BP86 \\
2S-1 & 1954(666), 1974(892) \\
2T-1 & $1950(782), 1977(905)$ \\
\hline
\end{tabular}


3.1.5 $\left(\mathrm{Me}_{2} \mathrm{C}_{2} \mathrm{P}_{2}\right)_{2} \mathrm{Co}_{2}(\mathrm{CO})$. The lowest-energy $\left(\mathrm{Me}_{2} \mathrm{C}_{2} \mathrm{P}_{2}\right)_{2} \mathrm{Co}_{2}(\mathrm{CO})$ structure 1T-1 consists of a $\left(\mathrm{Me}_{2} \mathrm{C}_{2} \mathrm{P}_{2}\right)_{2} \mathrm{Co}$ sandwich functioning as a tridentate chelating ligand to a $\mathrm{Co}(\mathrm{CO})$ unit by forming two $\mathrm{P} \rightarrow$ Co dative bonds of lengths $\sim 2.39 \AA$ (B3LYP) or $\sim 2.31 \AA$ (B3LYP) and a $\mathrm{Co} \rightarrow$ Co dative bond of length $2.664 \AA$ (B3LYP) or $2.483 \AA$ (BP86) (Figure 7 and Table 9). This interpretation of the bonding in 1T-1 gives each cobalt atom a 17-electron configuration for a binuclear triplet. The remaining triplet $\left(\mathrm{Me}_{2} \mathrm{C}_{2} \mathrm{P}_{2}\right)_{2} \mathrm{Co}_{2}(\mathrm{CO})$ structures lie at least $\sim 14 \mathrm{kcal} / \mathrm{mol}$ in energy above 1T-1 and therefore are not discussed in this paper.

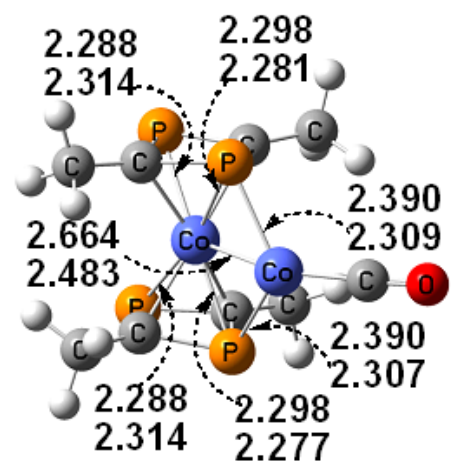

1T-1 $\left(C_{1}\right)$

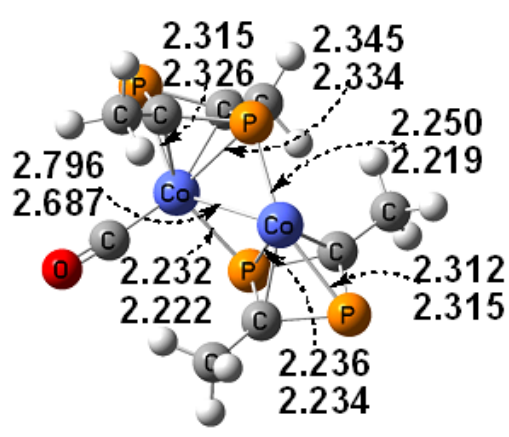

1S-1 $\left(C_{1}\right)$

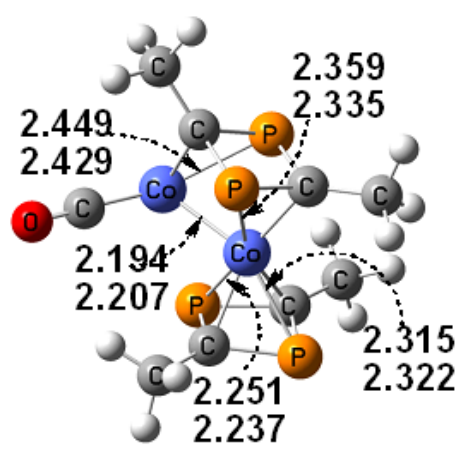

1S-2 $\left(C_{1}\right)$

Figure 7. Three optimized $\left(\mathrm{Me}_{2} \mathrm{C}_{2} \mathrm{P}_{2}\right)_{2} \mathrm{Co}_{2}(\mathrm{CO})$ structures with symmetry point groups in parentheses.

Table 9. Total energies ( $E$, in hartree), relative energies ( $\Delta E$, in $\mathrm{kcal} / \mathrm{mol})$, Co-Co distances $(\AA)$, and the $\mathrm{CO}$ vibrational frequencies $\left(\mathrm{cm}^{-1}\right.$, with the intensities in parentheses) for the four $\left(\mathrm{Me}_{2} \mathrm{C}_{2} \mathrm{P}_{2}\right)_{2} \mathrm{Co}_{2}(\mathrm{CO})$ structures. None of these structures has any imaginary vibrational frequencies.

\begin{tabular}{cccc}
\hline \hline & $\begin{array}{c}\text { 1T-1 } \\
\left(\mathrm{C}_{1},{ }^{3} \mathrm{~A}\right)\end{array}$ & $\begin{array}{c}\text { 1S-1 } \\
\left(\mathrm{C}_{1},{ }^{1} \mathrm{~A}\right)\end{array}$ & $\begin{array}{c}\text { 1S-2 } \\
\left(\mathrm{C}_{1},{ }^{1} \mathrm{~A}\right)\end{array}$ \\
\hline B3LYP & & & \\
$-\mathrm{E}$ & 4556.54835 & 4556.50215 & 4556.48438 \\
$\Delta \mathrm{E}$ & 0.0 & 29.0 & 40.1 \\
$\mathrm{Co}-\mathrm{Co}$ & 2.664 & 2.796 & 2.194 \\
$\left\langle\mathrm{~S}^{2}\right\rangle$ & 2.04 & 0.00 & 0.00 \\
\hline $\mathrm{BP} 86$ & & & \\
$-\mathrm{E}$ & 4557.09268 & 4557.08315 & 4557.07011 \\
$\Delta \mathrm{E}$ & 0.0 & 6.0 & 14.2 \\
$\mathrm{Co}-\mathrm{Co}$ & 2.483 & 2.687 & 2.207 \\
$\left\langle\mathrm{~S}^{2}\right\rangle$ & 2.02 & 0.00 & 0.00 \\
$v(\mathrm{CO})\left(\mathrm{cm}^{-1}\right)$ & $1962(1389)$ & $1951(816)$ & $1955(899)$ \\
\hline
\end{tabular}


The singlet $\left(\mathrm{Me}_{2} \mathrm{C}_{2} \mathrm{P}_{2}\right)_{2} \mathrm{Co}_{2}(\mathrm{CO})$ structure 1S-1 lies $29.0 \mathrm{kcal} / \mathrm{mol}$ (B3LYP) or $6.0 \mathrm{kcal} / \mathrm{mol}$ (BP86) in energy above 1T-1 (Figure 7 and Table 9). Again note the different singlet-triplet splittings predicted by the two DFT methods. The true value should lie between the B3LYP and BP86 values [41, 42, 43]. Structure 1S-1 has a terminal CO group and two bridging $\eta^{1}, \eta^{4}-\mathrm{Me}_{2} \mathrm{C}_{2} \mathrm{P}_{2}$ ligands. The Co-Co distance of $2.796 \AA$ (B3LYP) or $2.687 \AA$ (BP86) suggests a formal single bond. Thus the cobalt atom with a terminal CO group has the favored 18-electron configuration but the other cobalt atom has only a 16-electron configuration. The singlet $\left(\mathrm{Me}_{2} \mathrm{C}_{2} \mathrm{P}_{2}\right)_{2} \mathrm{Co}_{2}(\mathrm{CO})$ structure $\mathbf{1 S - 1}$ can be derived from the singlet $\left(\mathrm{Me}_{2} \mathrm{C}_{2} \mathrm{P}_{2}\right)_{2} \mathrm{Co}_{2}(\mathrm{CO})_{2}$ structure $\mathbf{2 S - 1}$ by loss of a $\mathrm{CO}$ group, which also leads to the shortening of the Co-Co distance by $\sim 0.1 \AA$.

The singlet $\left(\mathrm{Me}_{2} \mathrm{C}_{2} \mathrm{P}_{2}\right)_{2} \mathrm{Co}_{2}(\mathrm{CO})$ structure $\mathbf{1 S}-2$ is a relatively high energy structure, lying $40.1 \mathrm{kcal} / \mathrm{mol}$ (B3LYP) or $14.2 \mathrm{kcal} / \mathrm{mol}$ (BP86) above 1T-1 (Figure 7 and Table 9). However, 1S-2 is of interest in having an unusually short $\mathrm{Co} \equiv \mathrm{Co}$ distance of $2.194 \AA$ (B3LYP) or $2.207 \AA$ (BP86) as compared with any other of the $\left(\mathrm{Me}_{2} \mathrm{C}_{2} \mathrm{P}_{2}\right)_{2} \mathrm{Co}_{2}(\mathrm{CO})_{n}$ derivatives discussed in this paper. Structure 1S-2 has one terminal CO group, one terminal $\eta^{4}-\mathrm{Me}_{2} \mathrm{C}_{2} \mathrm{P}_{2}$ ligand bonded to the cobalt atom lacking the terminal $\mathrm{CO}$ group, and one bridging $\eta^{2}, \eta^{2}-\mathrm{C}_{2} \mathrm{P}_{2}$ ring. Interpreting the bridging $\eta^{2}, \eta^{2}-\mathrm{Me}_{2} \mathrm{C}_{2} \mathrm{P}_{2}$ ligand as a sixelectron donor to a central triply bonded $\mathrm{Co} \equiv \mathrm{Co}$ unit gives each cobalt atom in $\mathbf{1 S - 2}$ the favored 18-electron configuration.

The $v(\mathrm{CO})$ frequencies for the terminal $\mathrm{CO}$ groups in the $\left(\mathrm{Me}_{2} \mathrm{C}_{2} \mathrm{P}_{2}\right)_{2} \mathrm{Co}_{2}(\mathrm{CO})$ structures 1S-1, 1S-2 and 1T-1 range from 1951 to $1962 \mathrm{~cm}^{-1}$ (Table 9), as expected. The two structures has no bridge $\mathrm{CO}$ groups.

\subsection{Thermochemistry.}

Table 10 shows the dissociation energies for the reactions $\left(\mathrm{Me}_{2} \mathrm{C}_{2} \mathrm{P}_{2}\right)_{2} \mathrm{Co}_{2}(\mathrm{CO})_{n} \rightarrow$ $\left(\mathrm{Me}_{2} \mathrm{C}_{2} \mathrm{P}_{2}\right)_{2} \mathrm{Co}_{2}(\mathrm{CO})_{n-1}+\mathrm{CO}(n=5,4,3,2)$ considering the lowest energy structures. The dissociation energy for the loss of one $\mathrm{CO}$ group from $\left(\mathrm{Me}_{2} \mathrm{C}_{2} \mathrm{P}_{2}\right)_{2} \mathrm{Co}_{2}(\mathrm{CO})_{5}$ is nearly thermoneutral at $\sim 4 \mathrm{kcal} / \mathrm{mol}$ suggesting a species that is not viable. However, the $\mathrm{CO}$ dissociation energies for the other $\left(\mathrm{Me}_{2} \mathrm{C}_{2} \mathrm{P}_{2}\right)_{2} \mathrm{Co}_{2}(\mathrm{CO})_{n}$ species $(n=4,3)$ are significantly endothermic, ranging from 18 to $31 \mathrm{kcal} / \mathrm{mol}$ suggesting viability towards $\mathrm{CO}$ dissociation. In fact, these predicted $\mathrm{CO}$ dissociation energies for the $\left(\mathrm{Me}_{2} \mathrm{C}_{2} \mathrm{P}_{2}\right)_{2} \mathrm{Co}_{2}(\mathrm{CO})$ derivatives $(n$ $=4,3)$ are comparable to the experimental $\mathrm{CO}$ dissociation energies of 27,41 , and $37 \mathrm{kcal} / \mathrm{mol}$ for the stable metal carbonyls $\mathrm{Ni}(\mathrm{CO})_{4}, \mathrm{Fe}(\mathrm{CO})_{5}$, and $\mathrm{Cr}(\mathrm{CO})_{6}$, respectively [44]. The corresponding free energies $(\Delta \mathrm{G})$ are somewhat smaller (by 11 to $12 \mathrm{kcal} / \mathrm{mol}$ ), since the entropy values usually increase for dissociation processes. The free energies in 
Table 9 show that $\left(\mathrm{Me}_{2} \mathrm{C}_{2} \mathrm{P}_{2}\right)_{2} \mathrm{Co}_{2}(\mathrm{CO})_{5}$ is not stable, while the $\left(\mathrm{Me}_{2} \mathrm{C}_{2} \mathrm{P}_{2}\right)_{2} \mathrm{Co}_{2}(\mathrm{CO})_{n}$ species $(n=4,3)$ systems are stable towards CO loss.

Table 10. Dissociation energies $(\Delta \mathrm{E}, \mathrm{kcal} / \mathrm{mol})$ and the Gibbs free energies at $298 \mathrm{~K}(\Delta \mathrm{G}$, $\mathrm{kcal} / \mathrm{mol}$ ) for the successive removal of carbonyl groups from the lowest-lying for the $\left(\mathrm{Me}_{2} \mathrm{C}_{2} \mathrm{P}_{2}\right)_{2} \mathrm{Co}_{2}(\mathrm{CO})_{n}$ derivatives.

\begin{tabular}{|c|c|c|c|c|}
\hline & \multicolumn{2}{|c|}{ B3LYP } & \multicolumn{2}{|c|}{ BP86 } \\
\hline & $\Delta \mathrm{E}$ & $\Delta \mathrm{G}$ & $\Delta \mathrm{E}$ & $\Delta \mathrm{G}$ \\
\hline $5 \mathrm{~S}-1 \rightarrow 4 \mathrm{~S}-1+\mathrm{CO}$ & 2.4 & -9.5 & 6.6 & -5.0 \\
\hline $4 \mathrm{~S}-1 \rightarrow 3 \mathrm{~S}-1+\mathrm{CO}$ & 18.2 & 6.0 & 26.2 & 14.0 \\
\hline $3 S-1 \rightarrow 2 S-1+C O$ & 27.4 & 16.8 & 31.2 & 20.4 \\
\hline $\mathbf{2 S - 1} \rightarrow \mathbf{1 S}-1+\mathrm{CO}$ & 46.5 & 33.2 & 54.7 & 41.6 \\
\hline $\mathbf{2 S - 1} \rightarrow \mathbf{1 T - 1}+\mathrm{CO}$ & 17.5 & 1.8 & 48.7 & 33.5 \\
\hline $2(4 S-1) \rightarrow(5 S-1)+(3 S-1)$ & 15.8 & 15.5 & 19.7 & 19.0 \\
\hline $2(3 S-1) \rightarrow(4 S-1)+(2 S-1)$ & 9.2 & 10.7 & 5.0 & 6.5 \\
\hline $2(\mathbf{2 S - 1}) \rightarrow(3 \mathrm{~S}-1)+(\mathbf{1 S}-1)$ & 19.1 & 16.4 & 23.5 & 21.2 \\
\hline $2(2 S-1) \rightarrow(3 S-1)+(1 T-1)$ & -9.9 & -15.0 & 17.5 & 13.1 \\
\hline
\end{tabular}

The monotonic increase of the $\mathrm{CO}$ dissociation energies of the $\left(\mathrm{Me}_{2} \mathrm{C}_{2} \mathrm{P}_{2}\right)_{2} \mathrm{Co}_{2}(\mathrm{CO})_{n}$ derivatives with decreasing numbers of $\mathrm{CO}$ groups is consistent with the endothermic nature of the disproportionation processes $2\left(\mathrm{Me}_{2} \mathrm{C}_{2} \mathrm{P}_{2}\right)_{2} \mathrm{Co}_{2}(\mathrm{CO})_{n} \rightarrow\left(\mathrm{Me}_{2} \mathrm{C}_{2} \mathrm{P}_{2}\right)_{2} \mathrm{Co}_{2}(\mathrm{CO})_{n+1}$ $+\left(\mathrm{Me}_{2} \mathrm{C}_{2} \mathrm{P}_{2}\right)_{2} \mathrm{Co}_{2}(\mathrm{CO})_{n-1}(n=4,3,2)$ involving only singlet spin state structures (Table 9).

An alternative dissociation pathway for $\left(\mathrm{Me}_{2} \mathrm{C}_{2} \mathrm{P}_{2}\right)_{2} \mathrm{Co}_{2}(\mathrm{CO})_{n}$ is that into mononuclear $\left(\mathrm{Me}_{2} \mathrm{C}_{2} \mathrm{P}_{2}\right) \mathrm{Co}(\mathrm{CO})_{m}$ fragments. In order to obtain dissociation energies for such processes, the structures of the mononuclear $\left(\mathrm{Me}_{2} \mathrm{C}_{2} \mathrm{P}_{2}\right) \mathrm{Co}(\mathrm{CO})_{n}$ derivatives $(n=3,2$, 1) were optimized by the same DFT methods (Figure 8 and Table 11). For the tricarbonyl $\left(\mathrm{Me}_{2} \mathrm{C}_{2} \mathrm{P}_{2}\right) \mathrm{Co}(\mathrm{CO})_{3}$, the $\mathrm{Co}-\mathrm{C}$ distances range from 1.76 to $1.90 \AA$ and Co-P distances range from 2.31 to $2.74 \AA$, indicating the tetrahapto ring-metal bonding to give the cobalt atom a 19-electron configuration. Relatively small structural changes in the $\left(\eta^{4}-\mathrm{Me}_{2} \mathrm{C}_{2} \mathrm{P}_{2}\right) \mathrm{Co}$ unit were observed upon carbonyl loss. The cobalt atoms in $\left(\mathrm{Me}_{2} \mathrm{C}_{2} \mathrm{P}_{2}\right) \mathrm{Co}(\mathrm{CO})_{n}(n=2,1)$ have 17-electron and 15-electron configurations, respectively.

Using the above information (Table 11), the dissociation energies of the binuclear metal carbonyl derivatives into mononuclear fragments were obtained (Table 12). The predicted dissociation energies ( $\triangle \mathrm{E}$, in Table 12 ) range from 18 to $57 \mathrm{kcal} / \mathrm{mol}(\mathrm{B} 3 \mathrm{LYP})$ or 31 to $81 \mathrm{kcal} / \mathrm{mol}$ (BP86). These dissociation energies are strongly positive, indicating that the $\left(\mathrm{Me}_{2} \mathrm{C}_{2} \mathrm{P}_{2}\right)_{2} \mathrm{Co}_{2}(\mathrm{CO})_{n}$ derivatives are viable towards dissociation into mononuclear fragments. Similar to those in Table 10 , the free energies $(\Delta \mathrm{G})$ are lower by 16 to 
$23 \mathrm{kcal} / \mathrm{mol}$. All of the free energies except for $\mathbf{5 S - 1}$ are positive, indicating these complexes are stable toward the mononuclear fragment dissociation. For $\mathbf{5 S - 1}$, the $\Delta \mathrm{G}$ value is $-0.5 \mathrm{kcal} / \mathrm{mol}(\mathrm{B} 3 \mathrm{LYP})$ or $+14.9 \mathrm{kcal} / \mathrm{mol}$ (BP86). The true value should lie between these values. Table 11 also shows that the dissociation energies of $\left(\mathrm{Me}_{2} \mathrm{C}_{2} \mathrm{P}_{2}\right)_{2} \mathrm{Co}_{2}(\mathrm{CO})_{n}$ into mononuclear fragments increase monotonically with decreasing $n$.

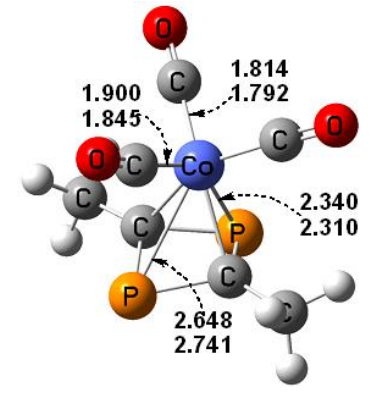

$\left(\mathrm{Me}_{2} \mathrm{C}_{2} \mathrm{P}_{2}\right) \mathrm{Co}(\mathrm{CO})_{3}$

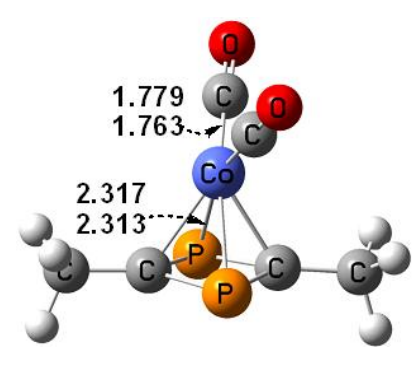

$\left(\mathrm{Me}_{2} \mathrm{C}_{2} \mathrm{P}_{2}\right) \mathrm{Co}(\mathrm{CO})_{2}$

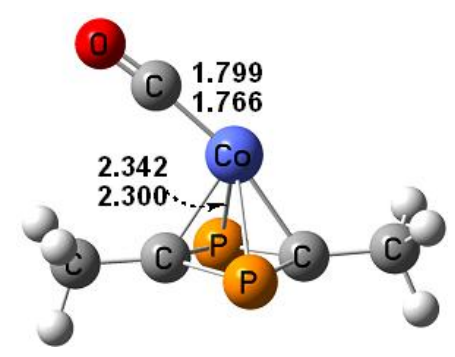

$\left(\mathrm{Me}_{2} \mathrm{C}_{2} \mathrm{P}_{2}\right) \mathrm{Co}(\mathrm{CO})$

Figure 8. The optimized structures for the mononuclear derivatives $\left(\mathrm{Me}_{2} \mathrm{C}_{2} \mathrm{P}_{2}\right) \mathrm{Co}(\mathrm{CO})_{n}(n$ $=3,2,1)$.

Table 11. Total energies $\left(E\right.$, in hartree) for $\left(\mathrm{Me}_{2} \mathrm{C}_{2} \mathrm{P}_{2}\right) \mathrm{Co}(\mathrm{CO})_{n}(n=3,2,1)$ and free $\mathrm{CO}$ used to calculate the dissociation energies in Table 12.

\begin{tabular}{lcccc}
\hline \hline & $\left(\mathrm{Me}_{2} \mathrm{C}_{2} \mathrm{P}_{2}\right) \mathrm{Co}(\mathrm{CO})$ & $\left(\mathrm{Me}_{2} \mathrm{C}_{2} \mathrm{P}_{2}\right) \mathrm{Co}(\mathrm{CO})_{2}$ & $\left(\mathrm{Me}_{2} \mathrm{C}_{2} \mathrm{P}_{2}\right) \mathrm{Co}(\mathrm{CO})_{3}$ & $\mathrm{CO}$ \\
& $\mathrm{C}_{\mathrm{s}}\left({ }^{2} \mathrm{~A}^{\prime \prime}\right)$ & $\mathrm{C}_{\mathrm{s}}\left({ }^{2} \mathrm{~A}^{\prime}\right)$ & $\mathrm{C}_{\mathrm{s}}\left({ }^{2} \mathrm{~A}^{\prime}\right)$ & $\mathrm{C}_{\infty \mathrm{v}}\left({ }^{1} \Sigma\right)$ \\
\hline B3LYP & -2334.906810 & -2448.298759 & -2561.640088 & -113.328658 \\
BP86 & -2335.184386 & -2448.590524 & -2561.943211 & -113.327235 \\
\hline
\end{tabular}

Table 12. Energies and the Gibbs free energies $(298 \mathrm{~K})$ for the dissociation of the binuclear $\left(\mathrm{Me}_{2} \mathrm{C}_{2} \mathrm{P}_{2}\right)_{2} \mathrm{Co}_{2}(\mathrm{CO})_{n}(n=5,4,3,2)$ derivatives into mononuclear fragments $(\mathrm{kcal} / \mathrm{mol})$.

\begin{tabular}{lcccc}
\hline \hline & \multicolumn{2}{c}{ B3LYP } & \multicolumn{2}{c}{ BP86 } \\
\cline { 2 - 5 } & $\Delta \mathrm{E}$ & $\Delta \mathrm{G}$ & $\Delta \mathrm{E}$ & $\Delta \mathrm{G}$ \\
\hline $\mathbf{5 S - 1} \rightarrow\left(\mathrm{Me}_{2} \mathrm{C}_{2} \mathrm{P}_{2}\right) \mathrm{Co}(\mathrm{CO})_{3}+\left(\mathrm{Me}_{2} \mathrm{C}_{2} \mathrm{P}_{2}\right) \mathrm{Co}(\mathrm{CO})_{2}$ & 17.9 & -0.5 & 31.4 & 14.9 \\
$\mathbf{4 S - 1} \rightarrow 2\left(\mathrm{Me}_{2} \mathrm{C}_{2} \mathrm{P}_{2}\right) \mathrm{Co}(\mathrm{CO})_{2}$ & 23.4 & 0.3 & 42.4 & 26.9 \\
$\mathbf{3 S - 1} \rightarrow\left(\mathrm{Me}_{2} \mathrm{C}_{2} \mathrm{P}_{2}\right) \mathrm{Co}(\mathrm{CO})_{2}+\left(\mathrm{Me}_{2} \mathrm{C}_{2} \mathrm{P}_{2}\right) \mathrm{Co}(\mathrm{CO})$ & 44.9 & 27.3 & 64.1 & 47.9 \\
$\mathbf{2 S - 1} \rightarrow 2\left(\mathrm{Me}_{2} \mathrm{C}_{2} \mathrm{P}_{2}\right) \mathrm{Co}(\mathrm{CO})$ & 57.2 & 37.0 & 80.8 & 62.4 \\
\hline \hline
\end{tabular}

\subsection{NBO Analysis of the Cobalt-Cobalt Bonding}

Table 13 lists the Wiberg Bond Indices (WBI) for the Co-Co bonds using NBO analysis with the BP86 functional [45]. The Co-Co distances, the formal Co-Co bond 
orders, and the bridging groups are also listed for comparison. Only the singlet structures are considered since WBI analyses of higher spin state structures appear to be less reliable.

Table 13. Atomic charges and Wiberg bond indices for the singlet $\left(\mathrm{Me}_{2} \mathrm{C}_{2} \mathrm{P}_{2}\right)_{2} \mathrm{Co}_{2}(\mathrm{CO})_{n}$ structures by the BP86 method.

\begin{tabular}{|c|c|c|c|c|c|}
\hline & $\begin{array}{c}\text { Co-Co } \\
\text { distance, } \AA\end{array}$ & $\begin{array}{c}\text { Formal } \\
\text { Bond order }\end{array}$ & $\begin{array}{c}\text { Wiberg } \\
\text { bond index }\end{array}$ & Bridges & $\begin{array}{c}\text { Natural Charge } \\
\text { on } \mathrm{Co} / \mathrm{Co}\end{array}$ \\
\hline $5 S-1$ & 4.369 & 0 & 0.01 & $\mathrm{Me}_{2} \mathrm{C}_{2} \mathrm{P}_{2}$ & $-0.11 /-0.03$ \\
\hline $5 S-2$ & 4.099 & 0 & 0.02 & $\mathrm{Me}_{2} \mathrm{C}_{2} \mathrm{P}_{2}$ & $-0.10 /-0.07$ \\
\hline $5 S-3$ & 3.600 & 0 & 0.04 & $\mathrm{CO}$ & $-0.02 /-0.02$ \\
\hline $5 S-4$ & 3.597 & 0 & 0.05 & $\mathrm{CO}$ & $-0.03 /-0.02$ \\
\hline $5 S-5$ & 3.587 & 0 & 0.05 & $\mathrm{CO}$ & $-0.03 /-0.02$ \\
\hline $4 S-1$ & 3.850 & 0 & 0.01 & $2 \mathrm{Me}_{2} \mathrm{C}_{2} \mathrm{P}_{2}$ & $-0.11 /-0.11$ \\
\hline $4 S-2$ & 2.505 & 1 & 0.14 & $2 \mathrm{CO}$ & $-0.01 /-0.01$ \\
\hline $4 S-3$ & 2.504 & 1 & 0.14 & $2 \mathrm{CO}$ & $-0.01 /-0.01$ \\
\hline $4 S-4$ & 2.731 & 1 & 0.14 & none & $-0.04 /-0.04$ \\
\hline 3S-1 & 2.758 & 1 & 0.13 & $\mathrm{Me}_{2} \mathrm{C}_{2} \mathrm{P}_{2}$ & $-0.04 /-0.06$ \\
\hline $3 S-2$ & 2.580 & 1 & 0.07 & $\mathrm{Me}_{2} \mathrm{C}_{2} \mathrm{P}_{2}$ & $-0.06 /-0.11$ \\
\hline 3S-3 & 2.515 & 1 & 0.09 & $\mathrm{CO}, \mathrm{Me}_{2} \mathrm{C}_{2} \mathrm{P}_{2}$ & $-0.06 /-0.06$ \\
\hline $3 S-4$ & 2.392 & 2 & 0.19 & $2 \mathrm{CO}$ & $0.14 /-0.04$ \\
\hline $3 S-5$ & 2.758 & 1 & 0.09 & $2 \mathrm{Me}_{2} \mathrm{C}_{2} \mathrm{P}_{2}$ & $-0.05 /-0.05$ \\
\hline $2 S-1$ & 2.781 & 1 & 0.12 & $2 \mathrm{Me}_{2} \mathrm{C}_{2} \mathrm{P}_{2}$ & $-0.01 /-0.01$ \\
\hline 1S-1 & 2.687 & 1 & 0.17 & $2 \mathrm{Me}_{2} \mathrm{C}_{2} \mathrm{P}_{2}$ & $-0.05 / 0.24$ \\
\hline 1S-2 & 2.207 & 3 & 0.36 & $2 \mathrm{Me}_{2} \mathrm{C}_{2} \mathrm{P}_{2}$ & $0.15 / 0.05$ \\
\hline $\mathrm{Co}_{2}(\mathrm{CO})_{8}$ & 2.55 & 1 & 0.1 & $2 \mathrm{CO}$ & \\
\hline
\end{tabular}

Previous studies on the Wiberg Bond Indices (WBIs) of metal carbonyls such as $\mathrm{Fe}_{2}(\mathrm{CO})_{9}$ and $\mathrm{Fe}_{3}(\mathrm{CO})_{12}$ show that the WBI values are relatively low compared with the formal bond orders, particularly when the metal-metal bonds are bridged by carbonyl groups [46]. For example, the WBI value for the Co-Co formal single bond in the doubly bridged $\mathrm{Co}_{2}(\mathrm{CO})_{8}$ structure is only 0.1 (Table 13). This is also true for the $\left(\mathrm{Me}_{2} \mathrm{C}_{2} \mathrm{P}_{2}\right)_{2} \mathrm{Co}_{2}(\mathrm{CO})_{n}$ derivatives, with no WBI values greater than 0.36. However, the relative WBIs of the cobalt-cobalt bonds still correlate well with the formal bond orders suggested by Co-Co distances and electron counting

The WBI values for the formal $\mathrm{Co}-\mathrm{Co}$ single bonds in the $\left(\mathrm{Me}_{2} \mathrm{C}_{2} \mathrm{P}_{2}\right)_{2} \mathrm{Co}_{2}(\mathrm{CO})_{n}$ derivatives are in the range from 0.07 to 0.17 . Most of the structures reported in this paper have $\mathrm{CO}$ or $\mathrm{Me}_{2} \mathrm{C}_{2} \mathrm{P}_{2}$ bridges. The WBI value for the formal $\mathrm{Co}=\mathrm{Co}$ double bond in 3S-4 is somewhat higher at 0.19. The WBI value for the formal $\mathrm{Co} \equiv \mathrm{Co}$ triple bond in $\mathbf{1 S - 2}$ is even higher at 0.36. The WBI values for non-bonding Co ${ }^{\cdots}$ Co interactions, such as those in all of the $\left(\mathrm{Me}_{2} \mathrm{C}_{2} \mathrm{P}_{2}\right)_{2} \mathrm{Co}_{2}(\mathrm{CO})_{5}$ structures and the $\left(\mathrm{Me}_{2} \mathrm{C}_{2} \mathrm{P}_{2}\right)_{2} \mathrm{Co}_{2}(\mathrm{CO})_{4}$ structure 4S-1 are predicted to be very small, namely from 0.01 to 0.05 . 


\section{Discussion}

The presence of two phosphorus atoms with lone pairs in the diphosphacyclobutadiene ligands in the $\left(\mathrm{Me}_{2} \mathrm{C}_{2} \mathrm{P}_{2}\right)_{2} \mathrm{Co}_{2}(\mathrm{CO})_{n}$ complexes leads to low-energy structures in which the cobalt atoms are linked by bridging $\eta^{1}, \eta^{4}-\mathrm{Me}_{2} \mathrm{C}_{2} \mathrm{P}_{2}$ or $\eta^{1}, \eta^{3}-\mathrm{Me}_{2} \mathrm{C}_{2} \mathrm{P}_{2}$ ligands rather than cobalt-cobalt multiple bonds. Structures containing only terminal $\eta^{4}-\mathrm{Me}_{2} \mathrm{C}_{2} \mathrm{P}_{2}$ ligands analogous to previously studied [19] phosphorus-free cyclobutadiene complexes $\left(\eta^{4}-\mathrm{C}_{4} \mathrm{H}_{4}\right)_{2} \mathrm{Co}_{2}(\mathrm{CO})_{n}$ are found, but typically at higher energies than their isomers containing bridging $\eta^{1}, \eta^{4}-\mathrm{Me}_{2} \mathrm{C}_{2} \mathrm{P}_{2}$ ligands that donate six-electrons to the central $\mathrm{Co}_{2}$ unit. Such behavior differs from that of the previously studied phospholyl complexes $\left(\mathrm{C}_{4} \mathrm{H}_{4} \mathrm{P}\right)_{2} \mathrm{Co}_{2}(\mathrm{CO})_{n}$ in which the phosphorus heterocycle ligand has only one phosphorus atom providing a lone pair. Thus the lowest energy structures of the phospholyl complexes $\left(\mathrm{C}_{4} \mathrm{H}_{4} \mathrm{P}\right)_{2} \mathrm{Co}_{2}(\mathrm{CO})_{n} \quad(n=3,2,1)$ are very similar to those of the corresponding cyclopentadienyl derivatives $\left(\mathrm{C}_{5} \mathrm{H}_{5}\right)_{2} \mathrm{Co}_{2}(\mathrm{CO})_{n}$.

Consider first the carbonyl-richest system studied in this work, namely the pentacarbonyl $\left(\mathrm{Me}_{2} \mathrm{C}_{2} \mathrm{P}_{2}\right)_{2} \mathrm{Co}_{2}(\mathrm{CO})_{5}$. In a $\left(\mathrm{Me}_{2} \mathrm{C}_{2} \mathrm{P}_{2}\right)_{2} \mathrm{Co}_{2}(\mathrm{CO})_{5}$ structure with terminal $\eta^{4}-\mathrm{Me}_{2} \mathrm{C}_{2} \mathrm{P}_{2}$ ligands, each cobalt atom can have the favored configuration even in the absence of a cobalt-cobalt bond. However, the rare feature of a bridging $\mathrm{CO}$ group not accompanied by a metal-metal bond is required to hold the two parts together in such a binuclear system. Structure 5S-3 (Figure 3) is of this type. However, 5S-3 lies $\sim 5 \mathrm{kcal} / \mathrm{mol}$ in energy above the lowest energy $\left(\mathrm{Me}_{2} \mathrm{C}_{2} \mathrm{P}_{2}\right)_{2} \mathrm{Co}_{2}(\mathrm{CO})_{5}$ structure 5S-1, which contains a single bridging $\eta^{1}, \eta^{3}-\mathrm{Me}_{2} \mathrm{C}_{2} \mathrm{P}_{2}$ ring that functions as a trihapto ligand to one cobalt atom and as a monohapto ligand to the other cobalt atom. The pentacarbonyl $\left(\mathrm{Me}_{2} \mathrm{C}_{2} \mathrm{P}_{2}\right)_{2} \mathrm{Co}_{2}(\mathrm{CO})_{5}$ does not appear to be a viable species since its $\Delta \mathrm{G}$ for $\mathrm{CO}$ dissociation to give the tetracarbonyl $\left(\mathrm{Me}_{2} \mathrm{C}_{2} \mathrm{P}_{2}\right)_{2} \mathrm{Co}_{2}(\mathrm{CO})_{4}$ is negative.

The permethylated cyclobutadiene cobalt carbonyl $\left(\mathrm{Me}_{4} \mathrm{C}_{4}\right)_{2} \mathrm{Co}_{2}(\mathrm{CO})_{4}$ has been synthesized but not yet structurally characterized by X-ray crystallography. ${ }^{21}$ The experimental observation of a strong bridging $v(\mathrm{CO})$ frequency at $1785 \mathrm{~cm}^{1}$ as well as a terminal $\mathrm{CO}$ frequency of $1978 \mathrm{~cm}^{-1}$ suggests a doubly bridged $\left(\eta^{4}-\mathrm{Me}_{4} \mathrm{C}_{4}\right)_{2} \mathrm{Co}_{2}(\mu-\mathrm{CO})_{2}(\mathrm{CO})_{2}$ structure analogous to the well-known related cyclopentadienyliron carbonyl $\left(\eta^{5}-\mathrm{C}_{5} \mathrm{H}_{5}\right)_{2} \mathrm{Fe}_{2}(\mathrm{CO})_{2}(\mu-\mathrm{CO})_{2}$. The doubly bridged $\left(\eta^{4}-\mathrm{Me}_{2} \mathrm{C}_{2} \mathrm{P}_{2}\right)_{2} \mathrm{Co}_{2}(\mu-\mathrm{CO})_{2}(\mathrm{CO})_{2}$ structures 4S-2 and 4S-3 (Figure 4) are of this type. The Co-Co bond distances in these structures of $\sim 2.52 \AA$ are very similar to the experimental value of $2.54 \AA$ found by X-ray crystallography for $\left(\eta^{5}-\mathrm{C}_{5} \mathrm{H}_{5}\right)_{2} \mathrm{Fe}_{2}(\mu-\mathrm{CO})_{2}(\mathrm{CO})_{2} \quad[47,48,49]$. The unbridged $\left(\eta^{4}-\mathrm{Me}_{2} \mathrm{C}_{2} \mathrm{P}_{2}\right)_{2} \mathrm{Co}_{2}(\mathrm{CO})_{4}$ structure $\mathbf{4 S - 4}$ has a similar energy to the doubly bridged structures $4 \mathrm{~S}-2$ and $\mathbf{4 S - 3}$ but a longer Co-Co distance of $\sim 2.74 \AA$ in accord with the absence of bridging $\mathrm{CO}$ groups. 
The lowest energy $\left(\mathrm{Me}_{2} \mathrm{C}_{2} \mathrm{P}_{2}\right)_{2} \mathrm{Co}_{2}(\mathrm{CO})_{4}$ structure 4S-1 has no cobalt-cobalt bond but two different types of bridging $\mathrm{Me}_{2} \mathrm{C}_{2} \mathrm{P}_{2}$ ligands. The bridging $\eta^{1}, \eta^{4}-\mathrm{Me}_{2} \mathrm{C}_{2} \mathrm{P}_{2}$ ligand donates four electrons from all ring atoms to one cobalt atom and two more electrons from a phosphorus lone pair to the other cobalt atom so it is a six-electron donor to the central $\mathrm{Co}_{2}$ unit. However, the bridging $\eta^{1}, \eta^{3}-\mathrm{Me}_{2} \mathrm{C}_{2} \mathrm{P}_{2}$ ligand donates three electrons to one cobalt atom through its trihapto linkage and one electron to the other cobalt atom through the phosphorus atom and thus is only a four-electron donor to the central $\mathrm{Co}_{2}$ unit. This combination of two different types of bridging ligands in the $\left(\mathrm{Me}_{2} \mathrm{C}_{2} \mathrm{P}_{2}\right)_{2} \mathrm{Fe}_{2}(\mathrm{CO})_{4}$ structure 4S-1 gives each cobalt atom the favored 18-electron configuration in the absence of a cobalt-cobalt bond.

The lowest energy structure of the binuclear cyclobutadienecobalt tricarbonyl $\left(\mathrm{C}_{4} \mathrm{H}_{4}\right)_{2} \mathrm{Co}_{2}(\mathrm{CO})_{3}$ is a singlet structure with two bridging $\mathrm{CO}$ groups and one terminal $\mathrm{CO}$ group. The doubly bridged $\mathrm{Co}=\mathrm{Co}$ distance of $\sim 2.41 \AA$ in this structure is appreciably shorter than the doubly bridged Co-Co single bond distance of $\sim 2.51 \AA$ and is thus interpreted as the formal double bond required to give each cobalt atom the favored 18-electron configuration. An analogous $\left(\eta^{4}-\mathrm{Me}_{2} \mathrm{C}_{2} \mathrm{P}_{2}\right)_{2} \mathrm{Co}_{2}(\mu-\mathrm{CO})_{2}(\mathrm{CO})$ structure 3S-4 having terminal $\eta^{4}-\mathrm{Me}_{2} \mathrm{C}_{2} \mathrm{P}_{2}$ ligands is found but at an energy $\sim 20 \mathrm{kcal} / \mathrm{mol}$ above the lowest energy isomer 3S-1 (Figure 5). Structure 3S-4 has a predicted $\mathrm{Co}=\mathrm{Co}$ distance of $\sim 2.41 \AA$, which is essentially identical to that of its cyclobutadiene analogue.

The lower energy $\left(\mathrm{Me}_{2} \mathrm{C}_{2} \mathrm{P}_{2}\right)_{2} \mathrm{Co}_{2}(\mathrm{CO})_{3}$ structures 3S-1, 3S-2, and 3S-3 all have one bridging $\eta^{1}, \eta^{4}-\mathrm{Me}_{2} \mathrm{C}_{2} \mathrm{P}_{2}$ ligand functioning as a six-electron donor across a $\mathrm{Co}_{2}$ unit with a Co-Co distance corresponding to a formal single bond (Figure 1). The combination of a six-electron donor bridging $\eta^{1}, \eta^{4}-\mathrm{Me}_{2} \mathrm{C}_{2} \mathrm{P}_{2}$ unit and a Co-Co single bond gives each cobalt atom in these three structures the favorable 18-electron configuration similar to the effect of a formal $\mathrm{Co}=\mathrm{Co}$ double bond and all terminal $\eta^{4}-\mathrm{Me}_{2} \mathrm{C}_{2} \mathrm{P}_{2}$ ligands such as found in 3S-4.

The lowest energy $\left(\mathrm{C}_{4} \mathrm{H}_{4}\right)_{2} \mathrm{Co}_{2}(\mathrm{CO})_{2}$ structure has two bridging $\mathrm{CO}$ groups with an ultrashort $\mathrm{Co} \equiv \mathrm{Co}$ distance of $\sim 2.2 \AA$ suggestive of the formal triple bond required to give each cobalt atom the favored 18-electron configuration. However, the lowest energy $\left(\mathrm{Me}_{2} \mathrm{C}_{2} \mathrm{P}_{2}\right)_{2} \mathrm{Co}_{2}(\mathrm{CO})_{2}$ structure 2S-1 (Figure 6) is very different with one terminal CO group on each cobalt atom and two six-electron donor $\eta^{1}, \eta^{4}-\mathrm{Me}_{2} \mathrm{C}_{2} \mathrm{P}_{2}$ rings bridging a relatively long formal Co-Co single bond of length $\sim 2.8 \AA$ to accommodate the geometry of the two bridging groups. The effect on electron bookkeeping of two six-electron donor bridging $\eta^{1}, \eta^{4}-\mathrm{Me}_{2} \mathrm{C}_{2} \mathrm{P}_{2}$ ligands across a Co-Co single bond is similar to a $\mathrm{Co} \equiv \mathrm{Co}$ triple bond and two terminal four-electron donor $\eta^{4}-\mathrm{Me}_{2} \mathrm{C}_{2} \mathrm{P}_{2}$ ligands. Thus each cobalt atom in 2S-1 has the favored 18-electron configuration. Structure $\mathbf{2 S - 1}$ is an unusually favorable 
structure since it lies $\sim 16 \mathrm{kcal} / \mathrm{mol}$ in energy below the next lowest energy singlet structures.

The lowest energy structure 1T-1 for the monocarbonyl is a sandwich structure in which a $\left(\eta^{4}-\mathrm{Me}_{2} \mathrm{C}_{2} \mathrm{P}_{2}\right)_{2} \mathrm{Co}$ unit functions as a tridentate ligand to a CoCO moiety by coordinating through the central cobalt atom as well as through a phosphorus atom from each $\mathrm{P}_{2} \mathrm{C}_{2}$ ring. The $\left(\eta^{4}-\mathrm{Me}_{2} \mathrm{C}_{2} \mathrm{P}_{2}\right) \mathrm{Co}$ ligand in 1T-1 is related to the known [9] $\left(\eta^{4}-\mathrm{tBu}_{2} \mathrm{C}_{2} \mathrm{P}_{2}\right)_{2} \mathrm{Co}$ with a 17 -electron cobalt configuration. The (tridentate)CoCO moiety also has a 17-electron configuration consistent with a binuclear triplet spin state for 1T-1.

\section{Summary}

Density functional theory studies show that the lowest energy $\left(\mathrm{Me}_{2} \mathrm{C}_{2} \mathrm{P}_{2}\right)_{2} \mathrm{Co}_{2}(\mathrm{CO})_{n}$ ( $n=5,4,3,2$ ) structures have bridging $\eta^{1}, \eta^{4}-\mathrm{Me}_{2} \mathrm{C}_{2} \mathrm{P}_{2}$ ligands donating six electrons to the central $\mathrm{Co}_{2}$ unit through a tetrahapto ring-metal linkage to one cobalt atom and a phosphorus lone pair to the other cobalt atom. For the tetracarbonyl $\left(\mathrm{Me}_{2} \mathrm{C}_{2} \mathrm{P}_{2}\right)_{2} \mathrm{Co}_{2}(\mathrm{CO})_{4}$ doubly CO-bridged structures with terminal $\eta^{4}-\mathrm{Me}_{2} \mathrm{C}_{2} \mathrm{P}_{2}$ ligands similar to known $\left(\eta^{5}-\mathrm{C}_{5} \mathrm{H}_{5}\right)_{2} \mathrm{Fe}_{2}(\mu-\mathrm{CO})_{2}(\mathrm{CO})_{2}$ and $\left(\eta^{4}-\mathrm{Me}_{4} \mathrm{C}_{4}\right)_{2} \mathrm{Co}_{2}(\mu-\mathrm{CO})_{2}(\mathrm{CO})_{2}$ structures lie only $\sim 5 \mathrm{kcal} / \mathrm{mol}$ in energy above the isomeric $\eta^{1}, \eta^{4}-\mathrm{Me}_{2} \mathrm{C}_{2} \mathrm{P}_{2}$ bridged structures. Structures with one or two bridging $\eta^{1}, \eta^{4}-\mathrm{Me}_{2} \mathrm{C}_{2} \mathrm{P}_{2}$ ligands, respectively, are preferred energetically for the unsaturated $\left(\mathrm{Me}_{2} \mathrm{C}_{2} \mathrm{P}_{2}\right)_{2} \mathrm{Co}_{2}(\mathrm{CO})_{3}$ and $\left(\mathrm{Me}_{2} \mathrm{C}_{2} \mathrm{P}_{2}\right)_{2} \mathrm{Co}_{2}(\mathrm{CO})_{2}$ systems over isomeric structures containing formal $\mathrm{Co}=\mathrm{Co}$ double bonds and $\mathrm{Co} \equiv \mathrm{Co}$ triple bonds, respectively. The lowest energy structure for the monocarbonyl $\left(\mathrm{Me}_{2} \mathrm{C}_{2} \mathrm{P}_{2}\right)_{2} \mathrm{Co}_{2}(\mathrm{CO})$ is a triplet structure in which a $\left(\mathrm{Me}_{2} \mathrm{C}_{2} \mathrm{P}_{2}\right)_{2} \mathrm{Co}$ sandwich unit functions as a tridentate ligand to a $\mathrm{CoCO}$ unit through a phosphorus atom on each ring as well as the central cobalt atom.

Acknowledgment. This research was supported by Funds for Sichuan Distinguished Scientists (Grant No. 2015JQ0042), Funds for the Youth Innovation Team of the Education Department of Sichuan Province (Grant No. 14TD0013) in China, and the U. S. National Science Foundation (Grant CHE-1057466).

Supporting Information. Tables S1-S31: Harmonic vibrational frequencies (in $\mathrm{cm}^{-1}$ ) and infrared intensities for the eight lowest singlet structures of $\left(\mathrm{Me}_{2} \mathrm{C}_{2} \mathrm{P}_{2}\right)_{2} \mathrm{Co}_{2}(\mathrm{CO})_{n} \quad(n=5$, 4, 3, 2, 1); Table S32: Cartesian coordinates for the 31 lowest energy structures of $\left(\mathrm{Me}_{2} \mathrm{C}_{2} \mathrm{P}_{2}\right)_{2} \mathrm{Co}_{2}(\mathrm{CO})_{n}(n=6,5,4,3)$; Tables S21-S24: Total energies, relative energies, and Co-Co distances for the eight lowest energy structures of $\left(\mathrm{Me}_{2} \mathrm{C}_{2} \mathrm{P}_{2}\right)_{2} \mathrm{Co}_{2}(\mathrm{CO})_{\mathrm{n}}(n=6,5,4$, 3); Tables S25-S28: Harmonic v(CO) vibrational frequencies predicted for the eight lowest energy $\left(\mathrm{Me}_{2} \mathrm{C}_{2} \mathrm{P}_{2}\right)_{2} \mathrm{Co}_{2}(\mathrm{CO})_{n}(n=6,5,4,3)$ structures; Table $\mathrm{S} 29$. Total energies for the mononuclear complexes $\left(\mathrm{Me}_{2} \mathrm{C}_{2} \mathrm{P}_{2}\right)_{2} \mathrm{Co}_{2}(\mathrm{CO})_{n}(n=3,2,1)$; Table S30. Complete Gaussian reference 39. 


\section{Literature References}

[1] K. B. Dillon, F. Mathey, J. F. Nixon, Phosphorus: The Carbon Copy: From Organophosphorus to Phospha-organic Chemistry, Wiley VCH, New York, 1998.

[2] F. Mathey, Tetrahedron Lett. (1976) 4155.

[3] F. Mathey, A. Mitschler, R. Weiss, J. Am. Chem. Soc., 100 (1978) 5748.

[4] X. Chen, Q. Du, R. Jin, H. Feng, Y. Xie, R. B. King, New J. Chem., 35 (2011) 1117.

[5] X. Chen, L. Yuan, G. Ren, Q. Xi, R. Jin, Q. Du, H. Feng, Y. Xie, R. B. King, Inorg. Chim. Acta, 445 (2016) 79.

[6] X. Chen, R. Jin, Q. Du, H. Feng, Y. Xie, R. B. King, J. Organometal. Chem., 701 (2012) 1.

[7] R. Wolf, A.W. Ehlers, M. M. Khusniyarov, F. Hartl, B. de Bruin, G. J. Long, F. Grandjean, F. M. Schappecher, R. Pöttgen, J. C. Slootweg, M. Lutz, A. L. Spek, K. Lammertsma, Chem. Eur. J. 2010, 16, 14322.

[8] T. Weitling, G. Wolmershäuser, P. Binger, M. Regitz, Chem. Comm. (1990) 1541.

[9] R. Wolf, A. W. Ehlers, J. C. Slootweg, M. Lutz, D. Gudat, M. Hunger, A. L. Spek, K. Lammertsma, Angew. Chem. Int. Ed. 47 (2008) 4584.

[10] R. Wolf, J. C. Slootweg, A. W. Ehlers, F. Hartl, B. de Bruin, M. Lutz, A. L. Spek, K. Lammertsma, Angew. Chem. Int. Ed. 48 (2009) 3104.

[11] P. Binger, B. Biedenbach, R. Schneider, M. Regitz, Synthesis-Stuttgart (1989) 960.

[12] E.-M. Rummel, M. Eckhardt, M. Bodensteiner, E. V. Peresypkina, W. Kremer, C. Gröger, M. Scheer, Eur. J. Inorg. Chem., (2014) 1625.

[13] M. Sebastian, M. Nieger, D. Szieberth, L. Nyulászi, E. Niecke, Angew. Chem. Int. Ed. 43 (2004) 637.

[14] L. Nyulászi, Z. Benko, Top Heterocycl. Chem. 19 (2009) 27.

[15] F. W. Heinemann, S. Kummer, U. Seiss-Brandl, U. Zenneck, Organometallics 18 (1999) 2021.

[16] C. Rödl, R. Wolf, Eur. J. Inorg. Chem., (2016) 736.

[17] X. Chen, R. Jin, Q. Du, H. Feng, Y. Xie, R. B. King, Polyhedron, 65 (2013) 298.

[18] X. Chen, L. Yuan, X. Wan, R. Jin, Q. Du, H. Feng, Y. Xie, R. B. King, Inorg. Chim. Acta, 446 (2016) 116.

[19] H. Wang, Y. Xie, R.B. King, H. F. Schaefer, Organometallics, 27 (2008) 3113.

[20] X. Chen, Q. Du, R. Jin, H. Feng, Y. Xie, R. B. King, Polyhedron, 73 (2014) 146.

[21] M. R. Cook, P. Härter, P. L. Pauson, J. Šraga, J. Chem. Soc. Dalton Trans., (1987) 2757.

[22] T. Ziegler, J. Autschbach, Chem. Rev., 105 (2005) 2695.

[23] M. Bühl, H. Kabrede, J. Chem. Theory Comput., 2 (2006) 1282.

[24] M. Brynda, L. Gagliardi, P. O. Widmark, P. P. Power, B. O. Roos, Angew. Chem. Int. Ed., 45 (2006) 3804.

[25] N. Sieffert, M. Bühl, J. Am. Chem. Soc., 132 (2010) 8056.

[26] P. Schyman, W. Lai, H. Chen, Y. Wang, S. Shaik, J. Am. Chem. Soc., 133 (2011) 7977. 
[27] R. D. Adams, W. C. Pearl, Y.O. Wong, Q. Zhang, M. B. Hall, J. R. Walensky, J. Am. Chem. Soc., 133 (2011) 12994.

[28] R. Lonsdale, J. Olah, A. J. Mulholland, J. N. Harvey, J. Am. Chem. Soc., 133 (2011) 15464.

[29] A. D. Becke, J. Chem. Phys., 98 (1993) 5648.

[30] C. Lee, W. Yang, R. G. Parr, Phys. Rev. B, 37 (1988) 785.

[31] A. D. Becke, Phys. Rev. A, 38 (1988) 3098.

[32] J. P. Perdew, Phys. Rev. B, 33 (1986) 8822.

[33] V. Jonas and W. Thiel, J. Phys. Chem., 1995, 102, 8474.

[34] I. Silaghi-Dumitrescu, T. E. Bitterwolf and R. B. King, J. Am. Chem. Soc., 2006, $128,5342$.

[35] S. Huzinaga, J. Chem. Phys., 42 (1965) 1293.

[36] T. H. Dunning, J. Chem. Phys., 53 (1970) 2823.

[37] A. J. H. Wachters, J. Chem. Phys., 52 (1970) 1033.

[38] D. M. Hood, R. M. Pitzer, H. F. Schaefer, J. Chem. Phys., 71 (1979) 705.

[39] M. J. Frisch, et al. Gaussian 09, Revision A.02, Gaussian, Inc., Wallingford CT, 2009.

[40] B.N. Papas, H.F. Schaefer, J. Mol. Struct. (THEOCHEM) 768 (2006) 175.

[41] M. Reiher, O. Salomon, B. A. Hess, Theor. Chem. Acc., 107 (2001) 48.

[42] O. Salomon, M. Reiher, B. A. Hess. J. Chem. Phys., 117 (2002) 4729.

[43] J. N. Harvey, Structure and Bonding, 112 (2004) 151.

[44] L. S. Sunderlin, D. Wang, P. R. Squires, J. Am. Chem. Soc., 115(1993) 12060.

[45] F. Weinhold, C. R. Landis, Valency and Bonding: A Natural Bond Order DonorAcceptor Perspective, Cambridge University Press, Cambridge, England, U. K., 2005, pp. 32-36.

[46] H. Wang, Y. Xie, R.B. King, H.F. Schaefer, J. Am. Chem. Soc. 128 (2006) 11376.

[47] O. S. Mills, Acta Cryst., 11 (1958) 620.

[48] R. F. Bryan, P. T. Greene, J. Chem. Soc. A (1970) 3068.

[49] A. Mitschler, B. Rees, M. S. Lehmann, J. Am. Chem. Soc. 100 (1978) 3390. 